\title{
Hangi Lider, Kurumda Kalmayı Nasıl Sağlıyor? Çok Boyutlu İş Motivasyonunun Aracı Rolü
}

\author{
Aslı Göncü Köse \\ Çankaya Üniversitesi
}

\author{
U. Baran Metin \\ Utrecht Üniversitesi
}

\begin{abstract}
Özet
Yöneticilerin liderlik tipleri çalışanların iş motivasyonlarını en fazla etkileyen faktörler arasında yer almaktadır ancak, Türkiye'de hem bu etkileri hem de liderlik stillerinin çalışan motivasyonları aracılığı ile işle ilgili diğer sonuç değişkenleri üzerindeki etkilerini inceleyen araştırmalar az sayıdadır. Bu çalışmanın amacı, yöneticilerin babacan ve dönüşümcü liderlik stilleri ile çalışanların çok boyutlu iş motivasyonları arasındaki ilişkileri geçerliği ve güvenirliği test edilmiş bir ölçek kullanarak Türkiye örnekleminde incelemek (Çalışma 1); ayrıca, liderlik tipleri ile işten ayrılma niyetleri arasındaki ilişkilerde çok boyutlu iş motivasyonunun kısmi aracı rolünü test etmektir (Çalışma 2). Bu amaçla, Çalışma 1'de 456 çalışandan veri toplanmış ve Gagné ve arkadaşları (2014) tarafindan Öz Belirleme Kuramı (Deci ve Ryan, 1985) temel alınarak geliştirilen Çok Boyutlu İş Motivasyonu Ölçeği'nin (ÇBİMÖ) Türkçeye adaptasyon çalışması gerçekleştirilmiştir. Çalışma 2'de 388 çalışandan veri toplanmış ve önerilen model yapısal eşitlik modellemesi yöntemiyle test edilmiştir. Çalışma 1'in bulguları, ÇBİMÖ’nün diğer ülkelerde yapılan çalışmaların gösterdiği faktör yapılarına uyumlu bir yapı gösterdiğini ve yordayıcı geçerliği olduğunu ortaya koymuştur. Çalışma 2'nin bulguları, genel olarak iki liderlik stilinin de motivasyon tipleriyle önerilen ilişkileri gösterdiğini ancak, iş motivasyonlarının yalnızca dönüşümcü liderlik ile işten ayrılma niyetleri arasındaki ilişkide kısmi aracılık ettiğini göstermiştir. Bulgular, kuramsal ve uygulamaya yönelik çıkarımlar ile gelecekteki çalışmalara yönelik önerilerle birlikte tartışılmıştır.
\end{abstract}

Anahtar kelimeler: Babacan liderlik, dönüşümcü liderlik, öz-belirleme kuramı, çok boyutlu iş motivasyonu, işten ayrılma niyeti

\begin{abstract}
Supervisors' leadership styles are among the most important variables that influence employees' work motivation. However, in Turkey, only a limited number of studies examined the effects of leadership styles on employee motivations and on distal work-related outcomes via their influences on these motivations. The present study aimed to examine the links of paternalistic and transformational leadership with employees' work motivations by using a valid and reliable work motivation measure and to test the mediating roles of motivations in the relationships between leadership styles and employees' turnover intentions. In Study 1, data were collected from 456 employees and the Multidimensional Work Motivation Scale (MWMS; Gagné et al., 2014), which was developed within the framework of Self-Determination Theory (Deci \& Ryan, 1985), was adapted to Turkish. In Study 2, data were collected from 388 employees and the proposed model was tested using structural equation modeling. Study 1 revealed that the factor structure and the predictive validity results of the adapted MWMS were consistent with those of its versions in other languages. Study 2 showed that both leadership styles were associated with motivation dimensions in the proposed directions; however, motivations partially mediated only the link between transformational leadership and turnover intentions.
\end{abstract}

Keywords: Paternalistic leadership, transformational leadership, self-determination theory, multidimensional work motivation, turnover intention

Yazışma Adresi: Doç. Dr. Aslı Göncü Köse, Çankaya Üniversitesi Fen-Edebiyat Fakültesi Psikoloji Bölümü, Yukarıyurtçu Mahallesi Mimar Sinan Caddesi No:4 06530, Etimesgut / Ankara

E-posta: agoncu@cankaya.edu.tr

Gönderim Tarihi: 06.09.2018

Kabul Tarihi: 02.04.2019 
Motivasyon, bireyi eyleme geçmesi yönünde harekete geçiren, davranışlarını belli bir amaca hizmet edecek şekilde yönlendiren ve amaca ulaşana dek davranışın sürekliliğini sağlayan güç olarak tanımlanabilir (Steers ve Porter, 1991). Ancak, endüstri ve örgüt (E/Ö) psikolojisi alanında çok sayıda motivasyon kuramı bulunmakta ve her kuram farklı önermeler barındırmaktadır (Riggio, 2013). Steers, Mowday ve Shapiro'ya (2004) göre, hem farkl1 kuram ve önermelerden kaynaklanan kavram karmaşasını azaltmak, hem de uygulamadaki sorunlara daha sağlıklı yanıtlar sağlayabilmek için, motivasyon kuramlarının kültürler arası geçerliğini gösteren görgül araştırmalara ihtiyaç duyulmaktadır. Son yıllarda, kültürler arası geçerliği pek çok farklı araştırmada desteklenmiş olan motivasyon kuramlarından biri Öz Belirleme Kuramı (Deci ve Ryan, 1985)'dır. Öz Belirleme Kuramı (ÖBK) üç ana kategoriden oluşan çok boyutlu bir motivasyon modeli önermekte ve her bir kategoride yer alan motivasyon tipini artıran ve azaltan faktörlere yönelik çıkarımlar sunmaktadır (Deci ve Ryan, 1985; Deci ve Ryan, 2000). Önerilen üç ana kategori motivasyonsuzluk, içsel motivasyon ve dışsal motivasyondur. ÖBK'nın önermelerini iş yeri bağlamında test eden farklı araştırmalar, kuramın çıkarımlarının çalışan motivasyonuna uyarlanabildiğini ve desteklendiklerini göstermiştir (örn., Gagne, 2003; Gagné, Chemolli, Forest ve Koestner, 2008; Kuvaas, 2006a, 2006b).

Çalışan motivasyonuna en fazla etki eden faktörlerden biri olması sebebiyle, E/Ö psikolojisi alanında motivasyon konusu genellikle liderlik konusu ile birlikte ele alınmaktadır. Yöneticilerin liderlik tiplerinin çalışanların motivasyonlarına olan olumlu ve olumsuz etkileri alanyazında pek çok farklı çalışmada ele alınmış olmakla beraber (örn., Eyal ve Roth, 2011) Türkiye'de bu konuda yapıllmış olan çalışmalar batı yazını ile karşılaştırıldığında görece az sayıdadır (Göncü, Aycan ve Johnson, 2014). Batı alanyazınında pek çok araştırmaya konu olmuş ve çalışan motivasyonuna olumlu katkıları olduğu gösterilmiş olan liderlik tipi dönüşümcü liderliktir (Avolio ve Bass, 2001; Bass, 1999). Dönüşümcü liderlik tipi hem bireycilikte yüksek olan toplumlarda hem de toplulukçulukta yüksek olan kültürel bağlamlarda etkin bir liderlik tipi olarak kabul edilmektedir. Öte yandan, toplulukçuluk özelliği daha fazla öne çıkan kültürel bağlamlarda kabul gören bir diğer liderlik tipi ise babacan liderliktir (Aycan, 2006; Aycan, Schyns, Sun, Felfe ve Saher, 2013; Göncü, 2013). Az sayıda da olsa, ülkemizi de içeren bazı çalışmalarda babacan liderlik ti- pine sahip yöneticilerin çalışanların içsel motivasyonları üzerinde, dönüşümcü liderlik tipine sahip yöneticilerin gösterdiği olumlu etkilere sahip oldukları bulunmuştur (Göncü ve ark., 2014).

$\mathrm{Bu}$ araştırma, iki amaca yönelik olarak yapılan iki farklı çalışmadan oluşmaktadır. Birinci çalışmada, ÖBK'nın önerdiği çok boyutlu motivasyon modelinin Türk kültürel bağlamındaki geçerliğini sınamak amacıyla, Çok Boyutlu İş Motivasyonu Ölçeği'nin (ÇBİMÖ; Gagné ve ark., 2014) Türkçeye adaptasyonu gerçekleştirilmiştir. Bu çalışmada ayrıca, çok boyutlu iş motivasyonlarının Gagné ve arkadaşları (2014) tarafından önerilen ve kuramsal olarak ilişkili olan sonuç değişkenleri (çalışanların örgütsel ve duygusal bağlılıkları ve erteleme davranışları) üzerindeki yordayıcı geçerliği analiz edilmiştir. ${ }^{1}$

İkinci çalışmada, dönüşümcü liderlik tipi ve babacan liderlik tipine sahip yöneticilerin çalışanların ÖBK tarafından önerilen motivasyon tipleri üzerindeki benzer ve farklı etkileri, bu motivasyon tiplerinin liderlik stili ile işten ayrılma niyeti arasındaki ilişkide aracı rol oynadı ğ bütünsel bir model üzerinde test edilmiștir. Alanyazında ÖBK'nın önerdiği çok boyutlu motivasyon modeli yaygın olarak araştırılmış olsa da farklı liderlik tiplerinin bu motivasyon türleri üzerindeki etkilerine odaklanan ve bu etkilerin ikincil sonuç değişkenleriyle (örn., işten ayrılma niyeti) olan ilișkilerini kuramın önermeleri doğrultusunda inceleyen çalışmaların sayısı çok azdır (Olafsen, Halvari, Forest ve Deci, 2015). İkinci çalışma, kuramın önerdiği çalışan motivasyonu tipleri üzerinde hem evrensel bir liderlik tipi olarak kabul gören dönüşümcü liderliğin, hem de kültüre özgü bir liderlik tipi olarak kabul edilen babacan liderliğin etkilerini ve bu etkilerin iş yaşamında oldukça önemli bir sonuç değişkeni olan işten ayrılma niyetine olan yansımalarını araştıran ilk çalışma olarak hem alanyazına hem de uygulamaya katkı sunmay1 amaçlamıştır.

\section{Öz Belirleme Kuramı (ÖBK) ve Çalıșan Motivasyonu}

ÖBK, içsel ve dişsal motivasyon tiplerini kavramsallaştıran ve inceleyen araştırmalar sonucunda geliştirilmiş ve özellikle iş hayatındaki motivasyonlar ile farklı motivasyon tiplerinin sonuçlarını açıklayarak çıkarımlar yapan, çok boyutlu bir meta-kuram olarak tanımlanmaktadir (Deci ve Ryan, 2000; Deci, Vallerand, Pelletier ve Ryan, 1991; Shuck, Roberts ve Zigarmi, 2018). ÖBK'ya göre, çalışanların performansları ve iyilik halleri, işlerini yaparken yerine getirdikleri farklı görevler için sahip oldukları motivasyon tiplerinden etkilenmektedir (Deci,

1 Yakın bir zamanda Çivilidağ ve Şekercioğlu (2017) ÇBİMÖ'nün Türkçeye adaptasyonuna yönelik bir çalıșma yapmıșlardır. Ancak, ÇBİMÖ'nün kavramsal uyumu, geçerlik ve güvenirlik çalışmasının (Çalışma 1) verisi Haziran 2017'de yayınlanan Çivilidağ ve Şekercioğlu'nun araştırmasından önce (Ekim 2016-Aralık 2016 arasında) toplanmıștır ve dolayısıyla bu araștırmanın yazarları ölçek maddelerini kendileri tercüme/geri-tercüme sürecinden geçirmişlerdir. Ayrıca, Çivilidağ ve Şekercioğlu'nun (2017) çalışmasında açımlayıcı ve doğrulayıcı faktör analizi sonuçları ile madde test korelasyonları ve Cronbach alfa iç tutarlık katsayıları rapor edilmiş; ancak ölçek geçerliğine yönelik bir çalışma yapılmamıştır. 
Olafsen ve Ryan, 2017). Kurama göre, her motivasyon tipi işlevsel olarak farklı öncüllere ve çıtılıara sahiptir. ÖBK'ya göre bireysel motivasyon sürekli bir dizi üzerinde incelenebilir. Bu dizideki iki uç, bireysel motivasyonun iki uç noktasını simgeler. Gagné ve arkadaşları (2014) motivasyonun üç temel boyutunu bu dizi üzerinde konumlandırır. Bu üç temel boyut sırasıyla "motivasyonsuzluk", "dışsal motivasyon" ve "içsel motivasyon" olarak tanımlanmıştır.

Adından da anlaşıldığı gibi, motivasyonsuzluk bir eyleme yönelik kişinin motivasyonun olmaması şeklinde tanımlanır (Gagné ve ark., 2014). Bu boyutu sergileyen bireylerde öz belirleme arzusu eksiktir ve bu sebeple de davranışa geçiş için bir istek yoktur. Motivasyonsuzluk ÖBK'nın olumsuz ucunu temsil eder. Öte yandan aynı dizinin pozitif ucunda içsel motivasyon yer almaktadır. İçsel motivasyon kişinin kendi isteği doğrultusunda, gönüllü olarak ve seçerek gerçekleş̧irdiği eylemlerde ortaya çıkar. İçsel motivasyon, bir aktiviteyi kendi başına ilginç ve zevkli bulduğumuz için yaptı̆̆ımız zamanlarda sahip olduğumuz motivasyon türüdür. Deci ve arkadaşları (2017), çalışanların işlerini anlamlı ve değerli buldukları, içselleştirdikleri ve sahiplendikleri durumlar ile yaptıkları işler için açık geribildirim aldıkları ve desteklendikleri durumlarda içsel motivasyonlarının arttığıı önermektedirler. İçsel motivasyonun artması ise öğrenme, gelişim, performans, kurumla ve işle özdeşleşme ile genel iyilik hali gibi olumlu sonuç değişkenleriyle pozitif yönde ilişkilidir. Son olarak dışsal motivasyon ise maddi ve/ya manevi ç1karlar karşıllığında yapılan işlerde ve/veya güç ilişkilerinin bir sonucu olarak gerçekleştirilen eylemlerde görülen motivasyon tipidir. Bu tip motivasyon, bir aktiviteyi belli ödüllere ulaşmak için, eleştiriden veya cezadan kaçmak için veya özsaygımızı arttırmak amacıyla yaptığımız zamanlarda sahip olduğumuz motivasyon türüdür. Dışsal motivasyon çalışanların hedeflenen sonuçlara ulaşmak adına kısa vadeli amaçlar koymalarına ve işlerinde daha az çaba harcamalarına yol açmakta; bu sonuçlar ise uzun vadede düşük performansa ve işle özdeşleşme, aidiyet hissi gibi olumlu sonuçlarda azalmalara neden olmaktadır.

ÖBK'ya göre içsel motivasyondan farklı olarak, dışsal motivasyonun farklı alt boyutları bulunmaktadır (Deci ve Ryan, 2000). Bu alt boyutlar, içselleştirme derecelerine göre çeşitlilik göstermektedir (Gagné ve ark., 2014). "Dıştan gelen düzenleme", bir işi ödüllere ulaşmak veya cezadan kaçmak için yapmak olarak tanımlanmaktadır (Ryan ve Deci, 2017) ve içselleştirilmemiş bir motivasyon türünü ifade eder. Bir çalışanın yaptığı bir işi sadece yöneticisinin olumsuz eleştirilerinden kaçınmak için yapması, dıştan gelen düzenlemeyle yapılan bir işe örnektir. "İçe yansıtılmış motivasyon" bir davranışı utanç, suçluluk hissi gibi içsel baskıların yönlendirmesiyle yapmamızı sağlayan motivasyon türüdür. Burada var olan içselleştirme ise dışsal etkenler tarafindan kontrol edilmektedir (Shuck ve ark., 2018). Örneğin, bir işi kendisiyle gurur duymak veya kendisinden utanç duymamak için iyi yapan bir çaış̧anın motivasyonu, içe yansıtılmış motivasyondur. Son olarak, "özdeşleştirilmiş düzenleme" bireyin bir işi kendisiyle özdeşleştirdiği değerlerle uyumu sebebiyle yapması olarak tanımlanır. Bu tip motivasyonda istemli veya iradi bir içselleştirme vardır. Örneğin, işini kendi kişisel değerleriyle uyumlu bulduğu için iyi yapmaya gayret gösteren bir çalışanın motivasyon tipi özdeşleştirilmiş düzenlemedir. ÖBK'ya göre, içsel motivasyon ve özdeşleştirilmiş düzenleme türleri özerk olarak düzenlenmiş, istemli ve daha içsel iken; dıştan gelen düzenleme ve içe yansıtılmış motivasyon türleri kontrollü olarak düzenlenmiş, daha az istemli ve daha dışsaldırlar (Ryan ve Deci, 2017). Alanyazındaki pek çok araştırma özerk motivasyon türleri olarak tanımlanan içsel motivasyon ve özdeşleştirilmiş düzenlemenin örgütsel vatandaşlık davranışları, iş performansı, iyilik hali, iş doyumu gibi olumlu sonuç değişkenlerini pozitif yönde yordadığını göstermektedir (Deci ve Ryan, 2000, 2008; Gagné ve ark., 2014; Parker, Jimmieson ve Amiot, 2017; Shuck ve ark., 2018).

ÖBK'nın bir diğer temel önermesi ise bireylerin psikolojik gelişmeye yönelik eğilimleri olduğu ve bu gelişimin üç temel ihtiyacın karşılanması koşulunda gerçekleștiğidir (Deci ve Ryan, 2000, 2008). Bu üç temel ihtiyaçtan biri özerkliktir ve bireyin eylemlerini kendi özgür iradesiyle, istemli ve kendi seçimleri doğrultusunda gerçekleştirmesi anlamına gelir (Deci ve Ryan, 2000, 2008). Kuramın tanımladığı bir diğer ihtiyaç yeterliktir ve bireyin çevresiyle olan etkileşiminde kendisini etkin olarak algilaması ve yeteneklerini ortaya koyabilmesi anlamına gelir (Deci ve Ryan, 2000; Trépanier, Forest, Fernet ve Austin, 2015). Son olarak, yakınlık ihtiyacı bireyin diğerleriyle anlamlı ilişkiler kurabilme ve sürdürebilme ihtiyacını temsil etmektedir (Deci ve Ryan, 2000). Bu üç ihtiyacın karşılanması çalışanların özerk motivasyonlarının, yani içsel motivasyon ve özdeşleştirilmiş düzenlemenin yüksek olmasıyla ilişkilidir (Gagné ve ark., 2014). Bu ihtiyaçların işyerinde karşılanmıyor ya da düşük seviyede karşılanıyor olması durumunda kontrollü motivasyon türlerinin, yani dıştan gelen düzenleme ve içe yansıtılmış motivasyon türlerinin yüksek olması beklenmektedir.

Çalışma 1: ÇBíMÖ'nün Kavramsal Uyumu, Geçerlik ve Güvenirlik Analizi

Küreselleşmenin son derece etkin olduğu günümüzde, geliştirilen davranış bilimleri ölçeklerinin de küresel genel-geçer kullanımının incelenmesi büyük önem taşımaktadır. ÖBK pek çok farklı kültürde benzeri yapıda kavramsallık göstermiş olduğu halde Türk kültüründe özellikle ÇBIMÖ'yü kullanarak yapılan çalıșmalara 
alanyazında rastlanmamıştır. Bu yüzden bu çalışmanın amacı ÇBİMÖ’nün hem kuramsal yapısını inceleyip alt boyutlarının özgün modele benzerliğini araştırmak hem de geçerlik ve güvenirlik çalışmasını yapmaktır. Ölçeğin ölçüt-bağıntılı geçerlik (yordama) geçerliği, Gagné ve arkadaşlarının (2014) çalışmalarıyla tutarlı olarak ÖBK boyutlarının örgütsel bağlılık (Allen ve Meyer, 1990) ve işyerinde erteleme davranışı (Metin, Taris ve Peeters, 2016) ile ilişkisi üzerinden incelenmiştir.

Genel olarak örgütsel bağlılık, çalışanların kurumun veya örgütün değer ve hedeflerini benimsemesi, kurumun yararı için çaba harcamaya istekli olması ve kendini kuruma ait hissetmesi olarak tanımlanmaktadır (Armstrong, 1998; Mowday, Steers ve Porter, 1997). Örgütsel bağl1lık temel olarak üç alt boyutla incelenmektedir. Bunlar duygusal bağlılık (çalıșanın ișyerine karşı sevgi beslemesi, değerler ve hedeflerinin uyuştuğunu hissetmesi), devam bağlılığ (çalışanın işyerine yaptığ1 yat1rımlar ve/ya ayrılmanın getireceği maliyetler sebebiyle işyerinde kalmayı bir ihtiyaç olarak görmesi) ve normatif bağlılıktır (çalışanın işyerinde kalmayı zorunluluk ve/ ya gereklilik olarak görmesi). Bu çalışmada Gagné ve arkadaşlarının (2014) çalışmasında olduğu gibi, geçerlik analizi için sadece duygusal bağlılık ele alınmıştır. Bunun nedeni ise duygusal bağlılığın ÖBK'nın önerdiği motivasyon boyutlarıyla olan güçlü uyumudur. Duygusal bağlılığın çalışanların motivasyonsuzluğuyla olumsuz, dışsal motivasyonlarıyla anlamsız, içe yansıtılmış düzenleme ve içsel motivasyonlarıyla ise giderek artan ve pozitif yönde ilişkiler göstermesi beklenmektedir.

İşyerinde erteleme davranışı, yapılması hedeflenen bir işin nedensiz olarak kesin olmayan bir süre boyunca yapılmaması ve bunun yerine işle ilgisi olmayan uğraşlarla meşgul olunması anlamına gelmektedir (Metin ve ark., 2016). İşyerinde erteleme davranışı iki alt boyutla incelenebilir. Bunlar sırasıyla oyalanma (bir işin ne iş arkadaşlarına ne de şirkete zarar verme amacı gütmeden yapılmasının ertelenmesi) ve siber kaytarmadır (mesai saatleri içerisinde çevrimiçi cihazların uzun süreler boyunca kişisel amaçlar için kullanılması). İşte erteleme davranışı önceki çalışmalarda bir çeşit bilişsel az uyarılma ve sıkkınlık halinin sonucu olarak gösterilmiştir (Metin ve ark., 2016). Bu yüzden erteleme davranışı ile motivasyon alt boyutları arasında örgütsel bağlılığın tam tersi bir türde ilişki olması beklenmektedir. Erteleme davranışının motivasyonsuzlukla pozitif, dışsal motivasyonla anlamsız, içe yansıtılmış düzenleme ve içsel motivasyonla ise negatif ilişkiler göstermesi beklenmektedir.

\section{Örneklem \\ Yöntem}

$\mathrm{Bu}$ çalışmanın örneklemi 456 beyaz yakalı çalışandan oluşmaktadır. Katılımcılara kartopu yöntemiyle ulaşılmış; elde edilen veriler anket aracılığı ile ve gönüllülük bazında toplanmıştır. Katılımcıların \%51'i (232 kişi) kadınlardan oluşmaktadır. Katılımcıların ortalama yaşları 35.8 yıldır $(\mathrm{S}=24.3)$ ve $\% 75$ 'i yüksek eğitimi bitirmiştir. Katılımcılar ortalama 8.2 yıldır $(\mathrm{S}=9.0)$ şu anda bulundukları şirkette çalışmaktadırlar. Örneklemde en çok temsil edilen sektör 66 çalışanla (\%14.5) kamu sektörüdür ve kamu sektörünü sırasıyla 57 çalışanla eğitim sektörü (\%12.5) ve 37 çalışanla hizmet sektörü (\%8.1) takip etmektedir. Katılımcilardan 407'si tam zamanlı çalışmaktadır (\%89.3) ve 251'i kadroludur (\%55).

\section{Ölçekler}

Veriler anket aracılığ1 ile toplanmıştır ve ankette yer alan ölçeklerin yanı sıra katılımcılara yaşları, cinsiyetleri, mevcut işyerindeki çalışma süreleri ve eğitim düzeylerini içeren demografik sorular sorulmuştur. Çalışmada kullanılan ölçeklerden sadece ÇBİMÖ’nün Türkçe uyarlaması bulunmadığından bu ölçeğin maddeleri standart çeviri-tekrar çeviri yöntemiyle Türkçeye çevrilmiştir.

Çok Boyutlu İş Motivasyonu. Çok boyutlu iş motivasyonu Gagné ve arkadaşlarının (2014) geliştirdiği Çok Boyutlu İş Motivasyonu Ölçeği (ÇBİMÖ) kullanılarak ölçülmüştür. ÇBİMÖ Türkçeye standart çeviri-tekrar çeviri yöntemi kullanılarak uyarlanmıştır. Maddeler önce iki sosyal psikolog tarafından Türkçeye çevrilmiştir. Ardından, iki endüstri ve örgüt psikoloğu, çevrilmiş olan bu maddeleri İngilizceye geri çevirmiştir. Daha sonra, maddelerin anlam ve kültüre uygunlukları aynı psikologlar tarafından tartışılarak tekrar değerlendirilmiş ve ölçek son haline getirilmiştir (Ek-1).

ÇBİMÖ "Şu andaki işinizi yaparken neden gayret gösteriyorsunuz?" sorusuna yanıt olabilecek 19 madde ve ÖBK'nın ilgili boyutlarını ölçen beş alt ölçekten oluşmaktadır. $\mathrm{Bu}$ alt ölçeklerden motivasyonsuzluk üç madde (örn., "Göstermiyorum, çünkü işimde zamanımı gerçekten boşa harcadığımı hissediyorum”), dıştan gelen düzenleme (üç madde diştan gelen sosyal düzenleme ve üç madde diştan gelen maddi düzenleme için) toplam altı madde ile (örn., "Başkalarının (örneğin, amirim/yöneticim, meslektaşlarım, ailem, müşteriler) onayını almak için”) ölçülmektedir. İçe yansitılmış motivasyon dört (örn., "Çünkü böyle yapmak kendimle gurur duymamı sağlıyor”), özdeşleştirilmiş motivasyon üç (örn., "Çünkü bu iş için çaba harcamak, benim kişisel değerlerimle örtüşüyor”) ve içsel motivasyon üç (örn., "Çünkü işimi yaparken eğleniyorum”) madde ile ölçülmektedir. Kat1lımcılar değerlendirmelerini " 1 = kesinlikle katılmıyorum" ve "7 = kesinlikle katılıyorum" arasında değişen 7'li Likert tipi ölçeği kullanarak yapmışlardır.

Örgütsel Bağlllık. Örgütsel bağlılık Allen ve Meyer (1990) tarafından geliştirilen ve Türkçeye uyarlama 
Tablo 1. ÇBİMÖ DFA Sonuçları Karşılaştırması $(N=456)$

\begin{tabular}{lcccccccc}
\hline & $x^{2}$ & $d f$ & $x 2 / d f$ & $C F I$ & $T L I$ & NFI & GFI & RMSEA \\
\hline Model 1. & 713.87 & 144 & 4.96 & .84 & .81 & .81 & .86 & .09 \\
Model 2. & 553.22 & 127 & 4.36 & .88 & .85 & .85 & .88 & .09 \\
Model 3. & 646.94 & 142 & 4.56 & .86 & .83 & .83 & .87 & .09 \\
Model 4. & 483.23 & 124 & 3.90 & .90 & .87 & .86 & .89 & .08 \\
Model 5. & 553.22 & 127 & 4.36 & .88 & .85 & .85 & .88 & .09 \\
Model 6. & 428.14 & 121 & 3.54 & .91 & .89 & .88 & .90 & .08 \\
\hline
\end{tabular}

Not. Model 1. Özgün model, Model 2. İlerletilmiş özgün model. Model 3. "İçe Yansitılmış Motivasyon 1" maddesi olmadan özgün model. Model 4. "İçe Yansıtılmış Motivasyon 1" maddesi olmadan ilerletilmiş özgün model. Model 5. 5 faktörlü model. Model 6. İlerletilmiş 5 faktörlü model.

çalışması Wasti (1999) tarafından yapılan Örgütsel Bağl11ık ölçeğinin duygusal bağlılık alt ölçeğiyle ölçülmüştür. Duygusal bağl1lık alt ölçeği altı maddeden (örn., "Bu kuruluşun sorunlarını gerçekten kendi sorunlarım gibi hissediyorum") oluşmaktadır. Katılımcılar maddeleri "1 = kesinlikle katılmiyorum" ve "7 = kesinlikle katılıyorum" arasında değişen 7'li Likert tipi ölçeği kullanarak değerlendirmiştir. Bu çalışmada ölçeğin Cronbach alfa güvenirlik katsayısı .86 olarak bulunmuştur.

İşyerinde Erteleme Davranışı. İşyerinde erteleme davranışı Metin ve arkadaşlarının (2016) geliştirdiği İşyerinde Erteleme Davranışı Ölçeği ile ölçülmüştür. Bu ölçek iki alt boyuttan oluşmakta ve bu alt boyutlardan oyalanma sekiz madde (örn., "İşteyken uzun çay-kahve molaları veririm”), siber kaytarma ise dört madde (örn., "Bir iş gününde kişisel kullanımım amacıyla sosyal medya ağlarında (Facebook, Instagram, Twitter gibi) yarım saatten fazla zaman geçiririm”) içermektedir. Katılımcılar maddeleri “ 0 = hiçbir zaman” ve "6 = her zaman”) arasında değişen 7'li Likert tipi ölçeği kullanarak değerlendirmiştir. Bu çalışmada ölçeğin Cronbach alfa güvenirlik katsayıları oyalanma için .86, siber kaytarma için .74 olarak bulunmuştur.

\section{Işslem}

Çalışmadaki veriler SPSS 23.0 ve AMOS 25.0 (Arbuckle, 2013) paket programları kullanılarak analiz edilmiştir. Çalışma 1'deki ÇBİMÖ’nün faktör yapısının analizi, en çok olabilirlik hesaplama yöntemi kullanılarak Doğrulayıcı Faktör Analizi (DFA) modellerinin uyum katsayıları incelenerek gerçekleştirilmiştir. ÖBK alt boyutlarının geçerlik analizi, bu motivasyon alt boyutlarının örgütsel bağlılık ve iş yerinde erteleme davranışlarıyla aralarındaki korelasyonları test ederek yapılmıştır.

\section{Bulgular}

ÇBİMÖ’nün Türkçeye adaptasyonunun kavramsal uyumu ve psikometrik özellikleri değerlendirilirken, ön- celikle Gagné ve arkadaşlarının (2014) önerdiği özgün modelin mevcut örneklemdeki uyum iyiliği değerleri incelenmiştir. Hem özgün modelin hem de özgün modelde yapılan değişikliklerle oluşturulan ilerletilmiş modellerin uyum iyiliği değerleri Tablo 1'de gösterilmiştir. $\mathrm{Bu}$ sonuçlara göre özgün model (Model 1) örneklemde kabul edilemez uyum iyiliği göstermiştir $\left[\chi^{2}(144)=\right.$ $713.87, C F I=.84, \mathrm{TLI}=.81, \mathrm{NFI}=.81, \mathrm{GFI}=.86, \mathrm{RM}-$ SEA = .09]. Gözlemlenen değişim göstergelerine göre bazı gözlenen değişkenlerdeki hataların birbirleriyle ilişkide olduğu bir model analiz edilmiştir (Model 2). Bu model her ne kadar anlamlı bir ilerleme gösterse de beklenen uyum iyiliğini sağlamamıştır $\left[\chi^{2}(127)=553.22\right.$, $\mathrm{CFI}=.88, \mathrm{TLI}=.85, \mathrm{NFI}=.85, \mathrm{GFI}=.88, \mathrm{RMSEA}=$ .09]. Yapılan incelemede içe yansıtılmış motivasyon alt boyutunun maddelerinden biri ("Çünkü kendime bu işi yapabileceğimi kanıtlamak zorundayım”) ait olduğu alt ölçeğe düşük bir yüklenme (.40) göstermiştir ve yapılan Cronbach alfa güvenirlik analizine göre bu madde alt ölçeğin genel güvenirliğini de düşürmektedir $(\alpha=.69)$. Bu madde ölçekten çıkarıldığı zaman hem içe yansıtılmış motivasyon alt ölçeğinin Cronbach alfa değeri kabul edilebilir bir değere (.76) yükselmekte (Nunnally, 1977) hem de DFA uyum değerleri iyileşmektedir $\left[\chi^{2}(142)\right.$ $=646.94, \mathrm{CFI}=.86, \mathrm{TLI}=.83, \mathrm{NFI}=.83, \mathrm{GFI}=.87$, RMSEA = .09] (Model 3). Bu modelin de istenen uyum iyiliği değerleri göstermemesi üzerine Model 2'dekine benzer şekilde gözlenen değişkenlerdeki hata katsayılarının kuvvetli ilişki gösterenlerinin birbirleriyle ilişkide olmasına izin verilmiştir. Model 2'ye oranla ilerleme anlamlı olsa da $\left[\Delta \chi^{2}(3)=69.99, p<.01\right]$ ölçek yine de kabul edilebilir uyum iyiliği değerlerine sahip değildir $\left[\chi^{2}(124)=483.23, \mathrm{CFI}=.90, \mathrm{TLI}=.87, \mathrm{NFI}=.86, \mathrm{GFI}\right.$ $=.879, \mathrm{RMSEA}=.08]$.

Bu noktada kavramsal uygunluğundan ötürü diştan gelen düzenleme alt ölçeğinin maddi ve sosyal alt boyutlarının birleştirildiği beș boyutlu bir model (Model 5) incelenmiştir $\left[\chi^{2}(127)=553.22, \Delta \chi^{2}(17)=160.65, \mathrm{CFI}=.88\right.$, 


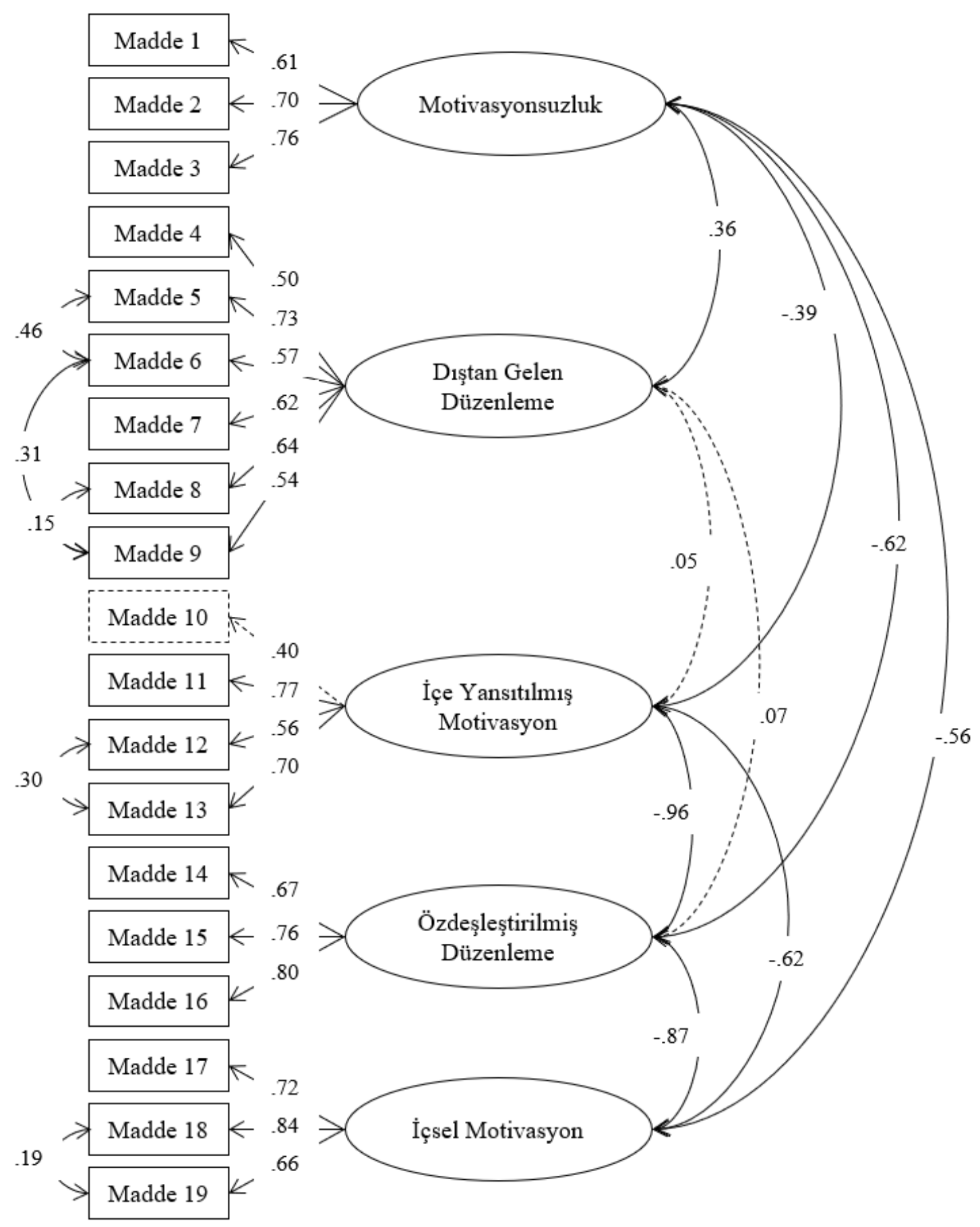

Şekil 1. ÇBİMÖ'nün Faktör Yapısı ve Maddelerin Faktörlere Yüklenme Katsayıları 
$\mathrm{TLI}=.85, \mathrm{NFI}=.85, \mathrm{GFI}=.87, \mathrm{RMSEA}=.09] . \mathrm{Bu}$ çözümleme gözlenen değişken hatalarının ilişkilendirilmediği Model 1 ve Model 3 'ten daha yüksek uyum iyiliği sonuçları gösterse de yine de DFA alanyazınında kabul edilen uyum değerlerinin altında kalmıştır. Bunun üzerine bu modelde önerilen değişim göstergeleri incelenmiş ve gerekli hataların birbirleriyle kovaryansları sağlanmıştır (Şekil 2). Bu modelde sekiz maddenin hata terimleri, ait oldukları alt boyuta ait maddelerin hata terimleriyle eşleştirildiğinde, gözlemlenen uyum iyiliği değerleri kabul edilebilir seviyededir $\left[\chi^{2}(121)=428.14, \Delta \chi^{2}\right.$ $(6)=125.08, \mathrm{CFI}=.91, \mathrm{TLI}=.89, \mathrm{NFI}=.88, \mathrm{GFI}=.90$, RMSEA $=.07]$. Alt ölçekler aynı zamanda birbirleriyle özgün modeldekine benzer yönlerde ve anlamlı korelasyonlar göstermiştir. Sadece diştan gelen düzenlemeyle içe yansitılmıș motivasyon $(r=.04, p=.38)$ ve diștan gelen düzenlemeyle özdeşleştirilmiş motivasyon ( $r=$ $.05, p=.19$ ) arasındaki korelasyonlar anlamlı seviyede değildir. Buna benzer sonuçlar Gagné ve arkadaşlarının (2014) önerdiği özgün modelin yedi farklı dile adaptasyonu çalışmasında da gözlenmiştir. Ancak temel olarak alt boyutlar arasındaki korelasyonlar beklenen yönlerdedir. Bu sonuçlar doğrultusunda beş boyutlu ve 18 maddeli ÇBİMÖ uyumlu olarak kabul edilmiş ve geçerlik analizlerine bu çözümlemeyle başlanmıştır (Şekil 1).

Son olarak ölçeğin güvenirlik ve geçerlik kriterleri incelenmiştir. ÇBİMÖ'nün alt boyutlarının Cronbach alfa güvenirlik katsayıları Tablo 2'de sunulmuştur. Geçerlik analizi için ise ölçeğin alt boyutlarının işyerine duygusal bağlılık ve işyerinde erteleme davranışı ile olan ilişkileri incelenmiştir. Korelasyon analizlerine göre motivasyonsuzluk $(r=-.44, p<.001)$ işyerine duygusal bağlılıkla negatif ve anlamlı bir ilişki göstermiştir (Tablo 2). Bunun yanı sıra duygusal bağlılık beklendiği gibi dişsal düzenlemeyle anlamlı bir ilişki göstermezken, içe yansitılmış düzenlemeden içsel motivasyona doğru giderek kuvvetlenen korelasyon katsayıları bulunmuştur (.32 - .45). Bu sonuçlar Gagné ve arkadaşlarının (2014) bulgularıyla örtüşmektedir.

Erteleme davranışı ise duygusal bağlılıkla karş1laştırıldığında motivasyon alt boyutlarıyla neredeyse zit nitelikte ilişkiler göstermiştir. Hem oyalanma $(r=.44$, $p<.001)$ hem de siber kaytarma $(r=-.25, p<.001)$ alt ölçekleri motivasyonsuzlukla pozitif bir ilişki ortaya koymuştur. Bunun yanı sıra iki ölçek de içe yansıtılmış motivasyondan içsel motivasyona doğru giderek artan negatif bir ilişki sergilemiştir (-.11 ve -.26). Sadece oyalanma alt boyutu özdeşleştirilmiş motivasyon ile -.32'lik bir korelasyon katsayısı göstermiştir ve bu katsayı içe yansıtılmış düzenleme ile karşılaştırıldığında daha kuvvetlidir. Ancak ilişki yine de beklenen yöndedir. Son olarak hem oyalanma $(r=.21, p<.001)$ hem de siber kaytarma $(r=.13, p=.01)$ davranışları dişsal motivasyon ile anlamlı ve pozitif bir ilişki göstermiştir. Bu sonuçlar doğrultusunda ÖBK alt boyutlarının hem duygusal bağlilıkla hem de erteleme davranışlarıyla alanyazındakine benzer ilişkiler gösterdiği saptanmıştır ve bu bulgular ÇBİMÖ’nün geçerliğini desteklemektedir.

Çalışma 2: Çok Boyutlu İş Motivasyonunun Liderlik Stilleri ve İşten Ayrılma Niyeti ile İlişkileri

Çalışma 1'de ÖBK'nın Türk örneklemindeki işleyişini ve batı yazınıyla uyumunu araştırmak amacıyla Gagné ve arkadaşlarının (2014) geliştirdiği ÇBİMÖ’nün Türkçeye adaptasyonu ve bu ölçeğin psikometrik özellikleri incelenmiştir. Sonuçlar, ÇBİMÖ’nün Türk örnekleminde batı yazınındakine benzer sonuçlar gösterdiğine, iş ve örgüt psikolojisi alanında yapılan araştırmalarda kullanılabilecek geçerli ve güvenilir bir ölçek olduğuna işaret etmektedir. Çalışma 2'nin amacı ise ÖBK'nın önerdiği motivasyon alt boyutlarının yöneticilerin dönüşümcü liderlik ve babacan liderlik stilleri ile ilişkilerini

Tablo 2. Çalışma 1'de Yer Alan Değişkenlerin Ortalama Değerleri, Standart Sapma ve Korelasyon Değerleri $(N=456)$

\begin{tabular}{lcccccccccc}
\hline & Ort. & $\mathrm{S}$ & 1 & 2 & 3 & 4 & 5 & 6 & 7 & 8 \\
\hline 1. Motivasyonsuzluk & 2.33 & 1.40 & $(.73)$ & & & & & & \\
2. Diş. gel. düzen.. & 3.00 & 1.33 & $.28^{* *}$ & $(.80)$ & & & & & \\
3. İçe yansit. moti. & 4.74 & 1.41 & $-.18^{* *}$ & $.28^{* *}$ & $(.76)$ & & & & \\
4. Özdeş. düzen. & 5.26 & 1.46 & $-.46^{* *}$ & .04 & $.64^{* *}$ & $(.79)$ & & & & \\
5. İçsel motivasyon & 4.46 & 1.52 & $-.41^{* *}$ & -.02 & $.41^{* *}$ & $.67^{* *}$ & $(.80)$ & & \\
6. Duygusal bağ. & 4.41 & 1.39 & $-.44^{* *}$ & -.06 & $.23^{* *}$ & $.40^{* *}$ & $.45^{* *}$ & $(.86)$ & \\
7. Oyalanma & 1.74 & 1.12 & $.44^{* *}$ & $.21^{* *}$ & $-.19^{* *}$ & $-.32^{* *}$ & $-.26^{* *}$ & $-.31^{* *}$ & $(.86)$ \\
8. Siber kaytarma & 2.42 & 1.37 & $.25^{* *}$ & $.13^{* *}$ & $-.11^{*}$ & $-.17^{* *}$ & $-.18^{* *}$ & $-.15^{* *}$ & $.51^{* *}$ & $(.74)$ \\
\hline
\end{tabular}

Not. ${ }^{*} p<.05,{ }^{* *} p<.01$. D1ş. gel. düzen.: Diştan gelen düzenleme. İçe yansıt. moti.: İçe yansıtılmış motivasyon. Özdeş. düzen.: Özdeşleştirilmiş düzenleme. Duygusal bağ.: Duygusal bağlılık. Parantez içinde sunulan değerler alt ölçeklere ait Cronbach alfa güvenirlik katsayılarıdır. 
incelemektir (Hipotez 1-5). Çalışmanın diğer bir amacı ise, çalışanların iş motivasyonlarının yöneticilerin dönüşümcü ve babacan liderlik stilleri ile çalışanların işten ayrılma niyetleri arasındaki ilişkilerdeki kısmi aracılık rolünü incelemektir (Hipotez 6-9).

\section{Dönüşümcü Liderlik ve Babacan Liderlik Stillerinin Motivasyon Türleri Üzerindeki Etkileri}

Dönüşümcü liderler takipçileri üzerinde büyük etkileri olan; grubun çıkarları ve iyiliği için takipçilerin kendi çıkarlarından fedakârlık etmelerini sağlayabilen; takipçilerinin hem bireysel özsaygılarını hem de grup üyeliğinden kaynaklanan özsaygılarını arttırabilen liderler olarak tanımlanırlar (Avolio ve Bass, 2001). Dönüşümcü liderliği oluşturan dört davranış boyutu vardır. Bu boyutlardan "idealleştirilmiş etki” liderin takipçilerin/çalışanların grupla özdeşleşmelerine ve belirlenen amaçlar doğrultusunda ilerlemek için fazladan çaba harcamalar1na neden olan bir misyon ve vizyon sağlaması olarak tanımlanmaktadır. "İlham verici motivasyon" takipçilerde/ çalışanlarda daha iyi bir geleceğe olan inancı ve morali arttırabilme becerisi anlamına gelmektedir. "Entelektüel uyarım", liderin zorlayıcı sorunların çözümünde takipçileri/çalışanları sıra dışı çözüm yolları bulmaları, yaratıcı ve girişimci olmaları konusunda cesaretlendirmesi ve teşvik etmesi olarak tanımlanır. "Kişiselleştirilmiş ilgi" boyutu ise liderin takipçilerin/çalışanların bireysel ihtiyaçlarına duyarlı olması ve onlarla birebir ilişkiler kurması anlamına gelmektedir.

Çalışanlara verilen görevlerin anlamlarını ve amaçlarını açıklayan, çalışanların bakış açılarını anlamaya çalışan, onların görüş ve duygularına önem veren, kontrolcü olmaktan çok çalışanlarına işlerini yaparken izledikleri yollar konusunda seçim hakkı veren yöneticiler işyerinde özerkliği teşvik eden ve destekleyen bir iklim yaratmaktadirlar (Deci, Connell ve Ryan, 1989; Gillet, Gagné, Sauvagere ve Fouquereau, 2013). Dönüşümcü liderlik stiline sahip yöneticiler, sergiledikleri davranışlarla özerkliği destekleyen bir yönetim stili ortaya koymaktadırlar. Dönüşümcü liderler, idealleştirilmiş etki yaratarak ve ilham verici motivasyon sağlayarak çalışanların yaptıkları işin anlamlılığına yönelik algılarını arttırmaktadırlar. Bu durumun, çalışanların özerklik ve yeterlik ihtiyaçları üzerinde olumlu etkileri olması beklenmektedir. Dönüşümcü liderlerin entelektüel uyarım sağlayarak çalışanlarını karşılaştıkları sorunlara yaratıcı ve özgün çözümler bulmaları konusunda cesaretlendirmeleri, çalışanların hem özerklik hem de yeterlik ihtiyaçlarının karşılanmasına katkı sağlayabilir. Gillet ve arkadaşları (2013) yöneticinin özerklik konusundaki algılanan desteğinin, çalışanların içsel motivasyonları ile özdeşleștirilmiș düzenlemeleri üzerinde pozitif etkisi olduğunu bulmuşlardır. Dönüşümcü liderlerin çalışanla- rına kişiselleştirilmiş ilgi göstermeleri, onların yakınlık ihtiyaçlarını karşılamalarına katkı sağlamaktadır. Tüm bu özellikleri ile dönüşümcü liderlik stiline sahip yöneticilerin çalışanların özerk motivasyonları; yani, içsel motivasyonları ile özdeşleştirilmiş düzenlemeleri üzerinde olumlu etkileri olması beklenmektedir. Bu önermelerle paralel olarak, Fernet, Trépanier, Austin, Gagné ve Forest (2015) dönüşümcü liderliğin fiziksel, sosyal ve duygusal iş kaynaklarını arttırdığını; iş kaynaklarındaki artışın da çalışanların özerk motivasyonlarını (içsel motivasyon ve özdeşleştirilmiş düzenleme) pozitif yönde etkilediğini bulmuşlardır.

Diğer yandan, dönüşümcü liderlik stiline sahip yöneticiler yarattıkları vizyon ve misyonun çalışanları tarafından benimsenmesini; çalışanların kurumun değerleri ve hedeflerini kendi değerleri ve hedefleri gibi sahiplenmelerini sağlamaktadırlar (Göncü ve ark., 2014). Dolay1sıyla, bu tip yöneticileri olan çalışanların işlerini yalnızca eleştiriden kaçınmak ya da suçluluk hissi gibi duyguları bertaraf etmek için yapmaları, yani dıştan gelen düzenleme ve/ya içe yansıtılmış motivasyon sebebiyle yapmaları beklenmemektedir. Türkiye'de yapılan ilișkili bir araştırmada da Göncü ve arkadaşları (2014) yöneticinin dönüşümcü liderlik stilinin çalışanların "dışsal bir motivasyonel süreç" olarak tanımlanan "lidere yönelik faydac1lık" motivasyonuyla olumsuz yönde ilișkili olduğunu bulmuşlardır. Ayrıca, çalışanların özerk motivasyonlarını arttırması beklenen dönüşümcü liderlerin, motivasyonsuzluklarını da azaltmaları beklenmektedir. Kuram ve önceki çalışmaların bulgularıyla uyumlu olarak, araştırmanın ilk iki hipotezi şu şekilde belirlenmiştir:

Hipotez 1: Yöneticilerin dönüşümcü liderlik stili ile çalışanların özerk motivasyonları (içsel motivasyonu ve özdeşleştirilmiş düzenlemeleri) arasında pozitif yönlü ilişki bulunacaktır.

Hipotez 2: Yöneticilerin dönüşümcü liderlik stili ile çal1şanların motivasyonsuzluğu ve kontrollü motivasyonları (dıştan gelen düzenleme ve içe yansıtılmış motivasyonu) arasında negatif yönlü ilişki bulunacaktır.

Öte yandan babacan liderlik, liderin ya da yöneticinin hem işle ilgili hem de özel hayatlarıyla ilgili olarak astlarına ya da çalışanlarına karşı koruyucu ve yol gösterici bir rol üstlendiği, hiyerarşik bir ilişki içermektedir. Bu liderlik stiline sahip yöneticiler, çalışanlarına bir aile büyüğü gibi davranır, çalışanlarına karşı tatl1-sert bir yaklaşım sergiler ve gerektiğinde onları dışarıdan gelen eleştirilere karşı da korurlar (Aycan, 2000). Karşılığında astların ya da çalışanların lidere ya da yöneticiye sadık ve itaatkâr olmaları beklenmektedir (Aycan, 2006). Aycan'a $(2000,2006)$ göre, babacan liderlik stili beş davranış boyutundan oluşmaktadır. Bunlar sırasıyla 1) işyerinde aile ortamı yaratmak, 2) çalışanlarla kișiselleştirilmiş ilişkiler kurmak, 3) çalışanların iş dışındaki hayatlarına 
dâhil olmak, 4) sadakat beklentisi içinde olmak ve 5) statü hiyerarşisini ve otoriteyi korumaktır.

Özellikle güç mesafesi yüksek ve yüksek seviyede toplulukçu olarak tanımlanan kültürel bağlamlarda babacan liderlik stili hem iş hayatında hem de diğer sosyal ortamlarda kabul görmekte ve benimsenmektedir. Özellikle ülkemizde yapılan bazı görgül çalışmalar, babacan liderlik stiline sahip yöneticilerin çalışanların yöneticiye duydukları güven, kuruma duydukları aidiyet hissi ve psikolojik yetkelenme hislerini arttırdığını (Göncü ve ark., 2014); çalışanların işe adanmışlıklarını pozitif yönde etkilediğini (Cem Ersoy, Born, Derous ve van der Molen, 2012); çalışanların işten ayrılma niyetleri ve erteleme davranışlarını ise azalttığını (Göncü Köse ve Metin, 2018) göstermişlerdir. Ancak şimdiye dek yapılan çalışmalar, yöneticilerin babacan liderlik stilinin hangi motivasyonel süreçleri ne şekilde etkilediğine ve hangi motivasyonel süreçler aracılığıyla bu olumlu ve olumsuz çıktıları yordadığına odaklanmamıştır.

Daha önce belirtildiği gibi, işlerini anlamlı ve değerli bulan, içselleştiren ve sahiplenen çalışanların içsel motivasyonlarının arttığı önerilmektedir (Deci ve ark., 2017). Ayrıca, yapılan işler için açık geribildirimler ve destek verilmesi de çalışanların içsel motivasyonlarını olumlu yönde etkilemektedir. İşyerinde bir aile ortamı yaratan ve çalışanlarıyla birebir ilişkiler kurarak onları hem işle ilgili konularda hem de özel hayatlarında destekleyen babacan liderlik stiline sahip yöneticilerin, çalışanların içsel motivasyonlarına olumlu katkıları olacağı önerilmektedir. Daha önce de tanımlandığı gibi, içsel motivasyon yerine getirilen görevlerden keyif almak ve bu sebeple yaptığını düşünmek anlamı taşımaktadır. Babacan liderlik stiline sahip yöneticiler çalışanların içsel motivasyonlarını, yarattıkları aile benzeri, samimi iş ortamları sayesinde artırıyor olabilirler. Çalışanların iş yerindeki genel psikolojik iyilik hallerini olumlu yönde etkilemesi beklenen bu tip kurumsal ortamların, çalışanların yaptıkları işi sıkıcı olarak algılamak yerine ilginç ve keyifli bir iş olarak algılamalarına katkı sağlayacağı önerilmektedir. Ayrıca, daha önce de belirtildiği gibi, ÖBK'nın temel önermelerinden biri bireylerin psikolojik gelişmeye yönelik eğilimleri olduğu ve bu gelişimin üç temel ihtiyacın karşılanması koşulunda gerçekleştiğidir (Deci ve Ryan, 2000, 2008). Bu üç temel ihtiyaçtan biri olan yakınlık bireyin diğerleriyle anlamlı ilişkiler kurabilme ve sürdürebilme ihtiyacını temsil etmektedir ve içsel motivasyonun önemli bir kaynağıdır (Deci ve Ryan, 2000). Babacan liderliğin de yeterlik ve özerklik ihtiyaçlarından çok çalışanların yakınlık ihtiyaçlarını karşılayan bir liderlik stili olduğu söylenebilir. Bunun yanında, Aycan $(2000,2006)$ kendilerini çalışanlarının bir aile büyüğü gibi gören babacan liderlerin çalışanlarına karşı sorumluluk hissettiklerini ve bu nedenle kişisel ve mesleki yeterliklerine katkıda bulunma çabası içinde olduklarını önermektedir. $\mathrm{Bu}$ önermeyle tutarlı olarak, ülkemizde yapılan bir çalışma babacan liderlik stilinin çalışanların psikolojik yetkelenme hislerini arttırdığını ve bu ilişkide yöneticiye duyulan güvenin tam aracı rol oynadığını göstermiştir (Göncü ve ark., 2014). Yine görece yakın bir zamanda yapılan çalışmada Karakitapoğlu-Aygün ve Gümüşlüoğlu (2013) dönüşümcü liderliğin etkileri kontrol edildiğinde, babacan liderliğin çalışanların psikolojik yetkelenme hislerini arttırdığını bulmuşlardır. Dolayısıyla, babacan liderlik stiline sahip yöneticilerin "iş yerinde aile ortamı yaratmak", "çalışanlarla kişisel ilişkiler kurmak" ve "çalışanların iş dışındaki hayatlarına dahil olmak" boyutlarının içsel motivasyonla pozitif bir ilişkiye sahip olacağı hipotez edilmektedir.

Diğer yandan, çalışanlarına bir aile büyüğü gibi davranan babacan yöneticiler, çalışanlarından kendi değerlerini ve kurumun değerlerini benimsemelerini bekleyebilirler. Bu beklentiye olumlu yanıt veren çalışanların, işlerini içselleştirdikleri bu değerlerle uyumlu olabilmek amacıyla iyi yapmaya çalıșmaları beklenmektedir. Dolayısıyla, babacan liderliğin çalışanların özdeşleştirilmiş düzenlemelerini de arttıracağı önerilmektedir. Ayrıca, içselleştirilen bu değerlerle uyumsuzluk olması durumunun, çalışanda kendinden utanma ve/ya suçluluk duygusunu tetiklemesi beklenmektedir. Bu duygulardan kaçınmak da çalışan için motivasyon kaynağı olabileceğinden, yöneticinin babacan liderlik stilinin aynı zamanda çalışanların içe yansıtılmış motivasyonunu da olumlu yönde etkileyeceği önerilmektedir.

Hipotez 3: Babacan liderlik stilinin "iş yerinde aile ortamı yaratmak", "çalışanlarla kişisel ilişkiler kurmak" ve "çalışanların iş dişındaki hayatlarına dahil olmak" boyutları ile çalışanların özerk motivasyonları (içsel motivasyonu ve özdeşleştirilmiş düzenlemeleri) ve içe yansıtılmış motivasyonu arasında pozitif yönlü ilişki bulunacaktır.

Diğer yandan, babacan liderlik stiline sahip yöneticiler statü hiyerarşisine önem veren ve bu hiyerarşik ilişkinin çalışanları tarafından da kabul görerek korunmasını bekleyen, bir aile büyüğü gibi koruyup kollad1ğ1 ve desteklediği çalıșanlarından bu tutumlarının karş1lı̆̆ında sadakat ve fedakârlık bekleyen yöneticilerdir (Aycan, 2000, 2006). Ebeveyn-çocuk ilişkisine de benzetilebilecek böyle bir ilişki örüntüsü içerisinde, çalışanlar için babacan yöneticinin onayını almak ve takdirini kazanmak önem arz etmektedir (Göncü, 2013). Babacan liderlik stiline sahip yöneticileri olan çalışanlar işlerini yöneticilerinden gelecek eleştirilerden kaçınmak, yöneticilerinden onay ve takdir görmek amaciyla iyi yapmaya çalışıyor olabilirler. Bu önermeyle tutarlı olarak, Göncü ve arkadaşları (2014) Türkiye'de gerçekleştirdikleri bir araştırmada babacan liderlik stilinin çalışanların izlenim 
yönetimi yapma eğilimleriyle pozitif ilişkili olduğunu bulmuşlardır. Dolayısıyla bu çalışmada da babacan liderlik stiline sahip yöneticilerin "sadakat beklentisi" ile "statü hiyerarşisi ve otoriteyi koruma" davranışlarının çalışanların sahip olduğu diştan gelen düzenleme motivasyon tipiyle pozitif yönde ilişkili olması beklenmektedir ${ }^{2}$.

Hipotez 4: Babacan liderlik stilinin "sadakat beklentisi" ve "statü hiyerarşisi ve otoriteyi koruma" boyutları ile çalışanların dıştan gelen düzenlemeleri arasında pozitif yönlü ilişsi bulunacaktır.

Son olarak, yöneticilerin farklı boyutları ile hem özerk motivasyonları (içsel motivasyon ve özdeşleştirilmiş düzenleme) hem de kontrollü motivasyonları (dışsal motivasyon ve içe yansıtılmış motivasyon) artırabildiği önerilen babacan liderlik stilinin, çalışanların motivasyonsuzluğu ile olumsuz yönde ilişkili olacağı önerilmektedir ve bir sonraki hipotez şu şekildedir:

Hipotez 5: Yöneticilerin babacan liderlik stili ile çalışanların motivasyonsuzluğu arasında negatif yönlü ilişski bulunacaktır.

\section{Dönüşümcü Liderlik ve Babacan Liderlik Stillerinin Çalışanların İş Yerinden Ayrılma Niyetleri Üzerindeki Etkileri ve Çalışan Motivasyonunun Kısmi Aracı Rolü}

İşten ayrılma niyetleri E/Ö psikolojisi ve örgütsel davranış alanlarında sıklıkla araştırılan bir konudur. Bunun en önemli nedenlerinden biri işten ayrılma niyetinin, işten ayrılma davranışını en iyi yordayan değişken olmasıdır (Shim, 2010) ve nitelikli çalışanların kendi istekleriyle işten ayrılması kurumlara oldukça maliyetli olabilmektedir (Alatawi, 2017). Ayrıca, işten ayrılma niyetlerinin kurumlarda çalışılması, bu niyetleri tetikleyen ve/ya arttıran faktörlerin belirlenmesini ve bu faktörlerin ortadan kaldırılması yönünde gerekli adımların atılmasını sağlayabilmektedir (Moynihan ve Landuyt, 2008). Yöneticilerin liderlik stili bu faktörlerin en önemlileri arasında yer almaktadır (örn., Abassi ve Hollman, 2000). Alanyazında yöneticilerin dönüşümcü liderlik stilinin çalışanların işten ayrılma niyetlerini azalttığını gösteren görgül çalışmalar mevcuttur (örn., Alatawi, 2017; Fu, Tsui, Liu ve Li, 2010; Green, Miller ve Aarons, 2013; Hughes, Avey ve Nixon, 2010). Ancak, dönüşümcü liderlerin hangi psikolojik ve motivasyonel süreçleri etkileyerek çalışanların işten ayrılma niyetlerini azalttık- larını araştıran az sayıda çalışma vardır (Caillier, 2016a, 2016b). Çalışanlarının içsel motivasyonunu ve özdeşleştirilmiş düzenlemelerini artıracağ 1 (Hipotez 1 ), dişsal ve içe yansıtılmış motivasyonları ile motivasyonsuzlukları$\mathrm{n} 1$ ise azaltacağı önerilen (Hipotez 2) bu çalışmada dönüşümcü liderlik stiline sahip yöneticilerin, çalışanlarda iş yerinden ayrılma düşüncesini de hem doğrudan hem de bu motivasyon türleri aracılığı ile azaltmaları beklenmektedir.

Hipotez 6: Yöneticilerin dönüşümcü liderlik stili ile çalışanların işten ayrılma niyetleri arasında negatif yönlü ilişki bulunacaktır.

Hipotez 7: Yöneticilerin dönüşümcü liderlik stili ile çalışanların işten ayrılma niyetleri arasındaki ilişkide çalışanların motivasyonu (motivasyon puanı) kısmi olarak arac1lik edecektir.

Babacan liderlik stilinin çalışanların işten ayrılma niyetleri üzerindeki etkilerini araştıran çalışmaların say1s1 görece azdır. Hipotez 3 ve 4 'te belirtildiği üzere bu çalışmada, yöneticinin babacan liderlik stilinin farklı alt boyutlarının çalışanların özerk (içsel motivasyon ve özdeşleştirilmiş düzenleme) ve kontrollü motivasyonlarını (dıştan gelen düzenleme ve içe yansıtılmış motivasyon) olumlu yönde etkilemesi beklenmektedir. Diğer yandan, yöneticilerin babacan liderlik stili ile çalışanların motivasyonsuzlukları arasında negatif yönlü bir ilișki önerilmektedir. Alanyazında babacan liderlik ve çalışanların işten ayrılma niyetleri arasındaki ilişkiye dair oldukça az sayıda bulgu sunulmuştur. Önceki çalışmalardan elde edilen genel sonuç ise, babacan liderlik stilinin özellikle "işyerinde aile ortamı yaratmak" ve "çalışanlarla kişisel ilişkiler kurmak" boyutları sebebiyle işten ayrılma niyetlerini doğrudan ve olumsuz yönde yordayabileceği; ayrıca, babacan liderlik stili ve çalışanların işten ayrılma niyetleri arasındaki ilişkide psikolojik sözleşme türü gibi aracı değişkenlerin rol oynayabileceği şeklindedir (Liao, Widowati, Hu ve Tasman, 2016; Uğurluoğlu, Uğurluoğlu Aldoğan, Turgut ve Özatkan, 2018). Dolayısıyla, bu çalışmada genel olarak iş yerinde aile ortamı oluşturan, çalışanlarıyla birebir ilişkiler kuran ve özel hayatlarına dâhil olan babacan yöneticilerin, çalışanların işten ayrılma niyetlerini hem doğrudan hem de (Hipotez 3 ile tutarlı olarak) özerk motivasyonları (içsel motivasyonu ve özdeşleştirilmiş düzenlemeleri) ve (Hipotez 5 ile tutarlı olarak) motivasyonsuzlukları aracılığı ile azaltacağ

2 Markus ve Kitayama’nın (1991) çalışmasından yola çıkarak, Türkiye gibi toplumlarda benliğin ilişkisel olduğu ve onaylanma, takdir edilme gibi ihtiyaçların "dışsal” motivasyonlardan çok "içsel” motivasyonlarla örtüşebileceği öne sürülebilir. Markus ve Kitayama'nın (1991) bulguları kabul etmeliyiz ki önemlidir; ancak, bu çalışma yaklaşık 25 sene öncesine dayanmakta ve iş hayatına odaklanmamaktadır. Türkiye bu süreçte hem kültürel hem de ekonomik olarak özelleştirme, küreselleşme ve uluslararası şirketlerin sayısının artması gibi ciddi değişiklikler yaşamıştır. Bu açıdan bakıldığında OECD (www.oecd.org) veya GLOBE (Chhokar, Brodbeck ve House, 2013) gibi endekslerde Türkiye'nin babacan liderliğin yine etkili olduğu Uzakdoğu kültürlerinden ziyade, Ortadoğu (Katar, Mısır, Kuveyt vb.) ülkeleri ile kümelenmekte olduğu bilgisi de önemlidir. Ayrıca, bu bulguları test eden Clark ve arkadaşları (2016) Türkiye'deki çalışma hayatının doğu ülkelerinden ziyade Anglo-Sakson ve Doğu Avrupa kültürleriyle daha kuvvetli ilişki gösterdiğini bulmuştur. 


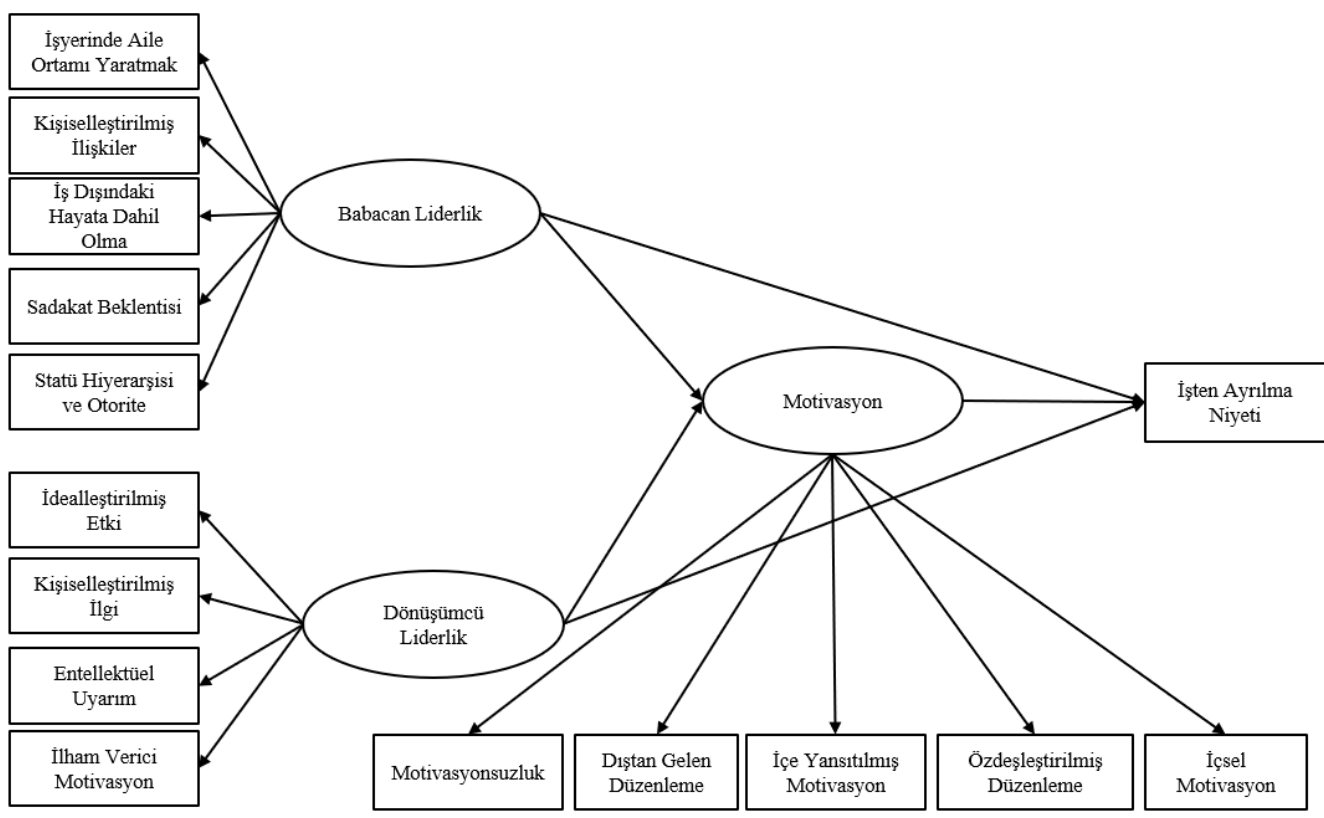

Şekil 2. Çalışma 2'de Önerilen Araştırma Modeli

düşünülmektedir ve araştırmanın son hipotezleri şu şekildedir (Şekil 2):

Hipotez 8: Yöneticilerin babacan liderlik stili ile çalışanların işten ayrılma niyetleri arasında negatif yönlü ilişki bulunacaktır.

Hipotez 9: Yöneticilerin babacan liderlik stili ile çalışanların işten ayrılma niyetleri arasındaki ilișkide çal1şanların motivasyonu (motivasyon puanı) kısmi olarak arac1lik edecektir.

\section{Yöntem}

\section{Örneklem}

$\mathrm{Bu}$ çalışmaya toplam 388 beyaz yakalı çalışan katılmıştır. Çalışma 1'de olduğu gibi, katılımcılara kartopu yöntemiyle ulaşılmış; elde edilen veriler anket tekniği kullanılarak ve gönüllülük bazında toplanmıştır. Katılımcılar toplanan verilerin bilimsel bir çalışma çerçevesinde kullanılacağına ve verdikleri yanıtların gizli kalacaklarına dair bilgilendirilmiştir. Katılımcıların \%55.4'ü (215 kişi) kadındır ve katılımcıların ortalama yaşları 35.3 yıldır $(S=10.7)$. Katılımcıların \%75.4'ü yükseköğretim mezunudur. Katılımcıların veri toplama sırasında çalıştıkları şirkette çalışma sürelerinin ortalaması 8.6 yıldır $(\mathrm{S}=9.7)$. Örneklemde en fazla çalışan 65 kişiyle (\%16.8) kamu sektöründendir ve ardından 50 kişiyle eğitim sektörü (\%12.9) ve 36 kişiyle hizmet sektörü (\%8.6) gelmektedir. Örneklemin \%90’1 tam zamanlı çalışmaktadır (347 kişi) ve \%52.8’i kadroludur (205 kişi).

\section{Ölçekler}

Çok Boyutlu İs Motivasyonu. Çok boyutlu iş motivasyonu Gagné ve arkadaşlarının (2014) geliştirdiği ve Çalışma 1'de Türkçeye geçerlik ve güvenirlik testleri yapılmış olan ÇBİMÖ kullanılarak ölçülmüştür. Bu çalışmada alt ölçeklerin Cronbach alfa iç güvenirlik katsayıları motivasyonsuzluk alt ölçeği için .74, dıştan gelen düzenleme için .80, içe yansıtılmış motivasyon için .76, özdeşleştirilmiş düzenleme için .78 ve içsel motivasyon için .77 olarak bulunmuştur (Tablo 3).

Babacan Liderlik. Yöneticilerin babacan liderlik seviyelerini ölçmek için Aycan (2006) tarafından geliştirilen 21 maddelik Babacan Liderlik Ölçeği kullanılmıştır [Örnek madde: "Doğrudan bağlı bulunduğum yönetici çalışanlarına karşı bir aile büyügüu (baba/anne veya ağabey/abla) gibi davranır"]. Katılımcılar maddeleri 5 basamaklı Likert tipi ölçek kullanarak değerlendirmişlerdir ( 1 = hiçbir zaman, 5 = her zaman). Yüksek puanlar yöneticinin babacan liderlik stilinin baskın olarak gözlemlendiğini göstermektedir. Bu çalışmada ölçeğin Cronbach alfa güvenirlik katsayısı .91 olarak bulunmuștur. Ölçeğin alt boyutlarının Cronbach alfa iç güvenirlik katsayıları .61 ve .82 arasında değişmektedir.

Dönüşümcü Liderlik. Yöneticilerin dönüşümcü liderlik seviyelerini ölçmek amacıyla Avolio, Bass ve Jung'un (1999) geliștirdiği 20 maddelik Çok Faktörlü Liderlik Anketi kullanılmıștır (Örnek madde: "Doğrudan bağlı bulunduğum yönetici güçlü bir amaç duygusuna sahip olmanın önemini vurgular”). Ölçeğin standardize 
edilmiş ve geçerlik çalışması yapılmış Türkçe versiyonu mevcuttur (http://www.mindgarden.com/products/mlqr. htm) ve daha önce de Türkiye' deki pek çok araştırmada kullanılmıştır (örn., Göncü ve ark., 2014). Katılımcılar maddeleri 5'li Likert tipi ölçek kullanarak değerlendirmişlerdir $(1=$ hiçbir zaman, 5 = her zaman). Yüksek puanlar yöneticinin dönüşümcü liderlik stilinin baskın olarak gözlemlendiğini göstermektedir. $\mathrm{Bu}$ çalışmada ölçeğin Cronbach alfa güvenirlik katsayısı 96 olarak bulunmuştur. Ölçeğin alt boyutlarının Cronbach alfa iç güvenirlik katsayıları .81 ve .90 arasında değişmektedir.

İșten Ayrılma Niyeti. İșten ayrılma niyeti Blau ve Boal'un (1989) geliştirdiği ve Bakoğlu Deliorman, Taştan Boz, Yiğit ve Yıldız (2009) tarafından Türkçeye uyarlanan dört madde ile ölçülmüştür (Örnek madde: "S1k sık işten ayrılmayı düşünüyorum"). Maddeler "1 = kesinlikle katılmiyorum" ve "5 = kesinlikle kat1liyorum" arasında değişen 5 basamaklı Likert tipi ölçek kullanılarak değerlendirilmiştir. Ölçekte elde edilen yüksek puanlar çalışanların işyerlerinden ayrılma niyetlerinin yüksek seviyede olduğunu ifade etmektedir. Ölçeğin Cronbach alfa iç güvenirlik katsayısı bu çalışmada .84 olarak bulunmuştur.

\section{İşlem}

Çalıșma 2'de bağımsız değișkenler ve motivasyon ölçeğinin alt boyutları arasındaki ilişkiler (ilk beş hipotez) korelasyon analizi kullanarak rapor edilmiş; geri kalan hipotezleri (Hipotez 6 - 9) içeren model analizleri ise yapısal eşitlik modellemesi (YEM) yöntemiyle test edilmiştir. Aracılı model analizi bootstrapping yöntemi kullanılarak incelenmiştir (Hayes ve Preacher, 2014). Hem DFA hem de yapısal eşitlik modelinin uyum iyiliği kıstası olarak Hu ve Bentler'in (1999) önerdiği uyum kriterleri esas alınmıştır.

\section{Bulgular}

$\mathrm{Bu}$ çalışmada yöneticilerin babacan liderlik stili ve alt boyutları ile dönüşümcü liderlik stilinin çalışanların iş motivasyonlarının alt boyutlarıyla nasıl bir ilişki gösterdiği ve çalışanların motivasyonunun yöneticilerin liderlik stilleriyle çalışanların işten ayrılma isteği arasındaki ilişkilerde kısmi aracılık rolüne sahip olup olmadığ1 incelenmiştir. Liderlik stilleriyle ÖBK alt boyutlarının arasındaki ilişkilere dair hipotezlerin testi korelasyon katsayıları ile, önerilen yol gösterici model ise YEM ile incelenmiştir. Hipotez 1 yöneticilerin dönüşümcü liderlik stili ile çalışanların özerk motivasyonları (içsel motivasyonu ve özdeşleştirilmiş düzenlemeleri) arasında pozitif yönlü ilişki olacağını önermiştir. Tablo 3'de gösterilen korelasyon analizi sonuçlarına göre dönüşümcü liderlik hem içsel motivasyonla hem de özdeşleştirilmiş düzenlemeyle pozitif ve anlamlı ilişki göstermektedir. Böylelikle Hipotez 1 desteklenmiştir. Hipotez 2'de yöneticilerin dönüşümcü liderlik stili ile çalışanların motivasyonsuzluğu ve kontrollü motivasyonları (dıştan gelen düzenlemeleri ve içe yansıtılmış motivasyonu) arasında negatif yönlü ilişki olacağı önerilmiştir. Yöneticilerin dönüşümcü liderlik stili ile çalışanların motivasyonsuzluğu arasında negatif yönlü ilişki varken; dönüşümcü liderlik stili ile çalışanların kontrollü motivasyonları (dıştan gelen düzenlemeleri ve içe yansıtılmış motivasyonu) arasındaki ilişki anlamlı seviyede değildir. Bu yüzden Hipotez 2 kısmen desteklenmiştir.

Hipotez 3 babacan liderlik stilinin "iş yerinde aile ortamı yaratmak", "çalışanlarla kişisel ilişkiler kurmak" ve "çalışanların iş dışındaki hayatlarına dahil olmak" boyutları ile çalışanların özerk motivasyonları (içsel motivasyonu ve özdeşleștirilmiş düzenlemeleri) ve içe yansıtılmış motivasyonu arasında pozitif yönlü ilişki bulunacağını öngörmüştür. Bulgulara göre, babacan liderlik stilinin belirtilen üç boyutu ile çalışanların özerk motivasyonları (içsel motivasyonu ve özdeşleștirilmiş düzenlemeleri) arasında pozitif yönlü ilişki vardır. Ancak, bu üç boyut ile çalışanların içe yansıtılmış motivasyonları arasındaki ilişkiler istatiksel olarak anlamlı seviyede değildir. Dolayısıyla, Hipotez 3 kısmen desteklenmiştir. Hipotez 4 babacan liderlik stilinin "sadakat beklentisi" ve "statü hiyerarşisi ve otoriteyi koruma" boyutları ile çalışanların dıştan gelen düzenlemeleri arasında pozitif yönlü ilişki bulunacağını önermiştir. Sonuçlara göre "sadakat beklentisi" alt boyutu ile diştan gelen düzenleme arasında istatiksel olarak anlamlı bir ilişki bulunmamıştır. Ancak, babacan liderlik stilinin "statü hiyerarşisi ve otoriteyi koruma" alt boyutu, beklendiği gibi çalışanların dıştan gelen düzenlemeleri ile pozitif yönde ilişkilidir. Dolayısıyla, Hipotez 4 de kısmen desteklenmiştir. Son olarak Hipotez 5 yöneticilerin babacan liderlik stili ile çalışanların motivasyonsuzluğu arasında negatif yönlü ilişki olacağını önermiştir. Sonuçlara göre babacan liderlik ile motivasyonsuzluk arasında negatif ve anlamlı bir ilişki vardır ve bu da Hipotez 5 'in desteklendiğini göstermektedir. Tek tek alt boyutlar incelendiğinde ise, "statü hiyerarşisi ve otoriteyi koruma" alt boyutu haricindeki diğer dört alt boyutun çalışanların motivasyonsuzluklarıyla negatif yönde ve anlamlı seviyede ilişkili olduğu bulunmuştur.

Bundan sonraki hipotezlerin incelenmesi için önerilen model (Şekil 3) YEM ile test edilmiştir. Önerilen modele göre yöneticilerin liderlik stilleri ile çalışanların işten ayrılma niyeti hem doğrudan hem de çalışanların iş motivasyonları aracılığı ile birbirleriyle ilişki göstermektedir. YEM analizi sonuçlarına göre kısmi aracılı model $\left[\chi^{2}(80)\right.$ $=290.03, \mathrm{CFI}=.95, \mathrm{TLI}=.93, \mathrm{NFI}=.93, \mathrm{GFI}=.91$, RMSEA = .08] tam aracılı modelle karşılaştırıldığında $\left[\chi^{2}\right.$ $(82)=302.69, \mathrm{CFI}=.95, \mathrm{TLI}=.93, \mathrm{NFI}=.93, \mathrm{GFI}=.91$, 


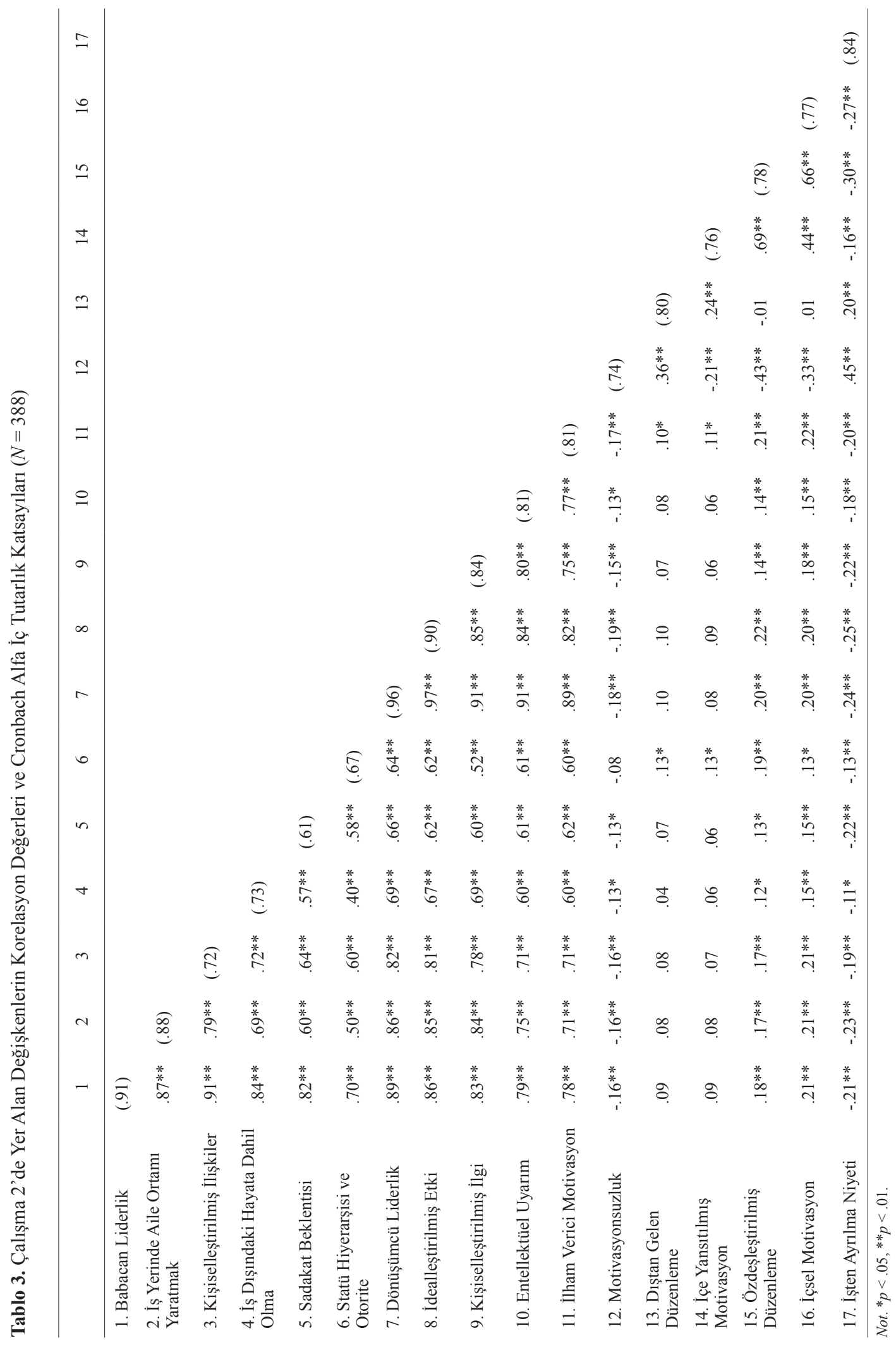




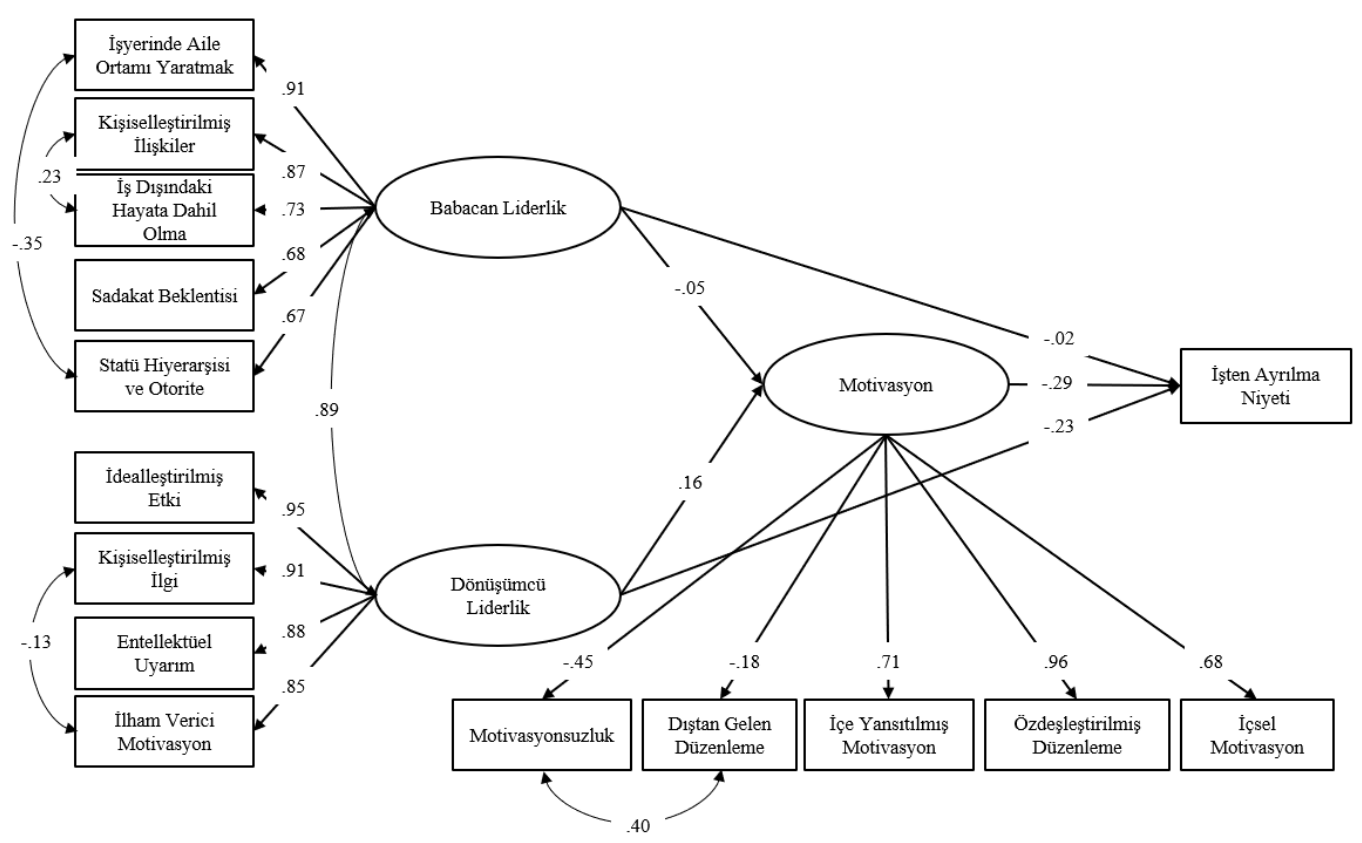

Şekil 3. Çalışma 2'de Önerilen Modelin Yapısal Eşitlik Modellemesi Analizi Sonuçları

$\operatorname{RMSEA}=.08]$ daha kuvvetli $\left(\Delta \chi^{2}(2)=12.66, p<.01\right)$ ve anlamlı seviyede daha yüksek ki-kare uyum endeksi göstermiştir (Tablo 4). Bu modele göre (bkz. Şekil 3) yalnızca yöneticilerin dönüşümcü liderlik stili ile çalışanların işten ayrılma niyeti arasında anlamlı ve negatif yönde bir ilişki saptanmıştır. Bunun yanı sıra bootstrapping yöntemiyle yapılan analizlere göre dönüşümcü liderlik ile işten ayrılma niyeti arasındaki dolaylı ilişki çalışan motivasyonu aracılığ 1 ile yordanmıştır $(\beta=-.17, S E=.09, p=.03$, GA[$.06,-.33])$. Böylece Hipotez 6 ve 7 desteklenmiștir. Buna karşın babacan liderlik stili ne çalışan motivasyonuyla $(\beta$ $=-.34, p=.09)$ ne de işten ayrılma niyetiyle $(\beta=.30, p=$ .11) anlamlı ilişki göstermektedir. Bu yüzden Hipotez 8 ve 9 desteklenmemiştir.

Son olarak, önerilen model ile, babacan liderliğin görece olumlu ("işyerinde aile ortamı yaratmak", "kişiselleştirilmiş ilişkiler", ve "iş dışındaki hayata dahil olma") ve görece olumsuz ("sadakat beklentisi" ve "statü hiyerarşisi ve otorite") olarak tanımlanabilecek alt boyutları ayrı gizil değişkenlere yüklenerek test edilmiştir. Ancak bu model, önerilen ve babacan liderliğin alt boyutlarının tek gizil değişkene yüklendiği modelle karŞılaştırıldığında, daha kötü uyum endeksleri göstermiştir $\left[\chi^{2}(81)=388.56, \mathrm{CFI}=.93, \mathrm{TLI}=.90, \mathrm{NFI}=.91, \mathrm{GFI}=\right.$ .88, RMSEA $\left.=.11 ; \Delta \chi^{2}(1)=85.87, p<.001\right]$ (Şekil 4). Ayrıca, bu modelde babacan liderliğin iki gizil değişkene ayrılan alt boyutları ile çalışan motivasyonu ve çalışanların işten ayrılma niyetleri arasındaki ilişkilerin istatistiksel olarak anlamlı seviyede olmadıkları görülmektedir. $\mathrm{Bu}$ bulgular, her ne kadar babacan liderlik alt boyutları anlamsal olarak olumlu ve olumsuz olarak ayrışabilse ve (k1smen desteklenen Hipotez 3 ve 4 ile desteklenen Hipotez 5 ile tutarlı olarak) farklı motivasyon türleriyle aynı yönde ancak farklı güçte ilişkiler gösterse de görgül ve deneyimsel olarak babacan liderliğin tek gizil değişkene yüklenen bir yapıya sahip olduğunu göstermektedir. $\mathrm{Bu}$ nedenle, özgün kurama bağlı kalınarak oluşturulan ve test edilen modelin, hem babacan liderliğin

Tablo 4. Tam aracı değişken ve kısmi aracı değişken modellerinin karşılaştırması $(N=388)$

\begin{tabular}{lcccccccc}
\hline & $x^{2}$ & $d f$ & $\Delta \mathrm{x}^{2}$ & $C F I$ & $T L I$ & $N F I$ & GFI & RMSEA \\
\hline Tam Arac1l Model & 302.69 & 82 & & .95 & .94 & .83 & .91 & .08 \\
Kismi Aracilı Model & 290.03 & 80 & $12.66^{* *}$ & .95 & .93 & .93 & .91 & .08 \\
\hline
\end{tabular}




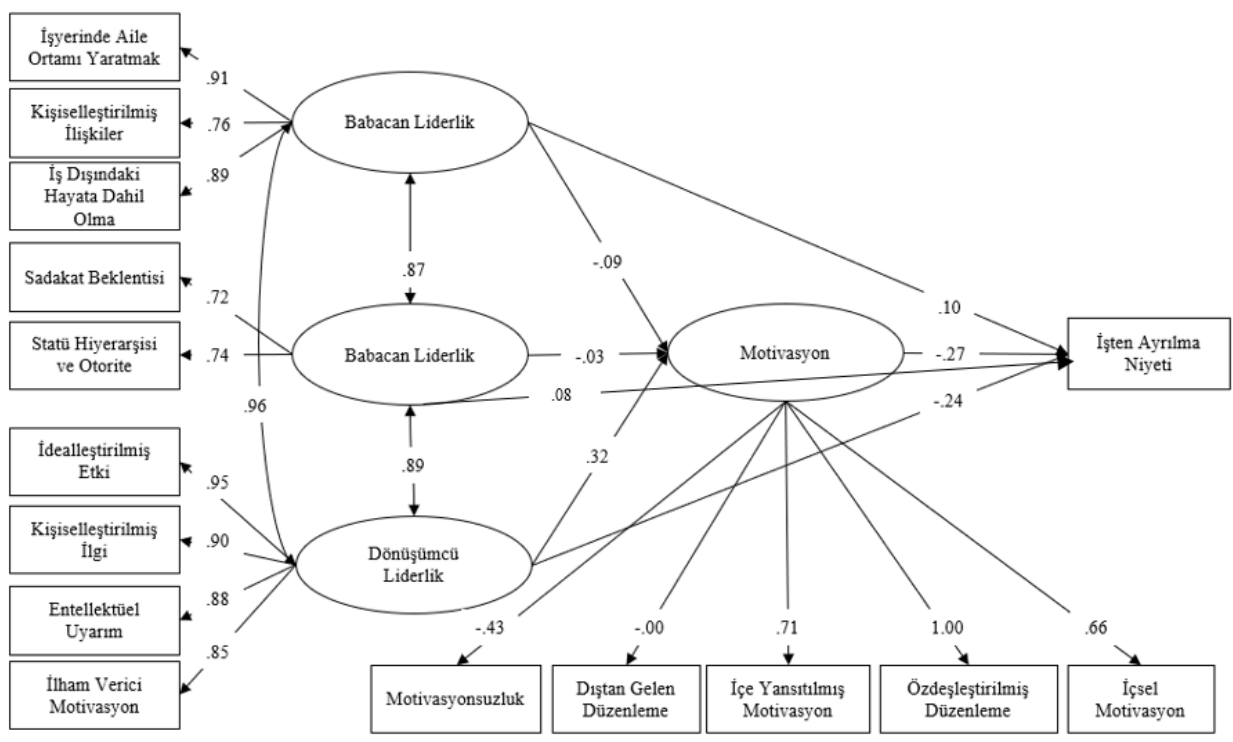

Şekil 4. Çalışma 2'de Önerilen Modelde Babacan Liderliğin İki Gizil Değişkene Yüklenerek Analiz Edildiği YEM Sonuçları

kuramsal ve deneyimsel yapısına yönelik alanyazındaki bulguları desteklediği, hem de daha iyi uyum endeksleri gösterdiği sonucuna varılmıştır. ${ }^{3}$

\section{Tartışma}

$\mathrm{Bu}$ çalışmaların esas olarak iki temel amacı vardır. İlk amaç ÇBİMÖ'nün Türkçeye adaptasyonunu hem güvenirlik hem de geçerlik çalı̧̧masını yaparak gerçekleştirmektir (Çalışma 1). İkinci amaç ise ÖBK'nın önermeleri doğrultusunda Çalışma 1 'de psikometrik özellikleri incelenen Türkçe ÇBIMÖ'yü kullanarak yaygın olarak araştırılan iki liderlik tipinin (dönüşümcü liderlik ve babacan liderlik) çalışanların işten ayrılma niyetleri ile olan ilişsilerinde motivasyon tiplerinin kısmi arac1lık rollerinin incelenmesidir (Çalışma 2). İki çalışmadan oluşan bu araștırma, ÇBIMÖ’yü yöntemsel olarak güçlü bir çalışma ile Türkiye'deki araştırmacıların hizmetine sunmanın yanında, ÖBK'nın önerdiği motivasyon tiplerinin bu iki liderlik stili ile olan ilişkilerini ilk kez bir çalışmada birlikte ele alarak ve önemli bir sonuç değișkeni olan çalışanların ișten ayrılma niyetleriyle ilișkilerini test ederek hem kurama hem de uygulamaya katk1 sağlamayı hedeflemiştir.

ÇBIMÖ şimdiye kadar dokuz farklı dile çevrilerek geçerlik ve güvenirlik çalışmaları yapılmış ve tutarlı so- nuçlar vermiş bir ölçektir (Gagné ve ark., 2014). Gagné ve arkadaşları (2014) bu durumun diğer iş motivasyonu ölçeklerine kıyasla ÇBİMÖ’nün daha gelişmiş bir ölçüm aracı olduğuna kanıt oluşturduğunu vurgulamaktadır. $\mathrm{Bu}$ araştırma kapsamında yapılan Çalışma 1'in bulguları, Türkçe ölçeğin de önceki çalıșmalarla tutarlı bir faktör yapısı, Cronbach alfa güvenirlik katsayıları ve geçerlik analizi sonuçları ortaya koyduğunu göstermiştir. Gagné ve arkadaşlarına (2014) göre ÇBİMÖ'yü diğer ölçeklerden ayırt eden bir diğer olumlu özelliği, dıştan gelen düzenleme alt ölçeğinin "dıştan gelen sosyal düzenleme" ve "dıștan gelen maddi düzenleme" olmak üzere iki farklı motivasyon tipini içermesidir. Ancak Çalışma 1'in sonuçları, Türkçe ölçekte bu iki alt boyutun farkl1laşmadığını ve aynı faktöre yüklendiklerini göstermiştir. Başka bir deyişle, örneklemde yer alan çalışanlar için işyerindeki diğer bireylerin onayını almak ve/ya eleştirilerinden kaçınmak için işini iyi yapmaya çalışmak (dıştan gelen sosyal düzenleme) ile işyerindeki diğer bireylerin sağlayabileceği maddi ödüllere ulaşmak ve/ya işini kaybetmemek için ișini iyi yapmaya çalıșmak (dıștan gelen maddi düzenleme) arasinda önemli bir fark yoktur. Burada kritik olan faktörün motivasyonun diş etkenler tarafından oluşturulması ve sürdürülmesi olduğu söylenebilir. Daha farklı ve yüksek sayıdaki örneklemlerle yapılacak gelecek araştırmalarda bu iki motivasyon alt

3 Görece olumlu ve görece olumsuz olarak nitelendirilebilecek babacan liderlik alt boyutlarının iki ayrı gizil değişkene yüklendiği model, motivasyon alt boyutlarının tek gizil değişkene yüklenmediği ve beş ayrı kısmi aracı değişken olarak ele alındıkları şekilde de analiz edilmiş; bu model hem önerilen özgün modele hem de yukarıda açıklanan ikinci modele göre daha zayıf uyum endeksleri göstermiştir $\left[\chi^{2}(54)=292.08, \mathrm{CFI}=.97, \mathrm{TLI}=.95, \mathrm{NFI}=.97, \mathrm{GFI}=.96, \mathrm{RMSEA}=.07 ; \Delta \mathrm{x}^{2}(26)=2.05, p>.05\right]$. 
boyutunun ayrışıp ayrışmadığı ve farklı sonuç değişkenleri ile olan ilişkileri incelenmelidir. Örneğin, sosyoekonomik statüsü yüksek olan çalışanlarda düşük olanlara kıyasla iş alternatiflerinin daha fazla olması, yetkinliğe dayalı özgüvenin yüksek seviyede olması gibi sebeplerle diştan gelen maddi düzenleme diştan gelen sosyal düzenlemeye kıyasla daha az baskın olabilir ve örgütsel bağlılık, iş doyumu ve işten ayrılma niyetleri gibi sonuç değişkenleri üzerinde daha az etkili olabilir.

Gagné ve arkadaşlarının (2014) belirttiği ve önceki çalışmalarda olduğu gibi, hem Çalışma 1'de hem de Çalışma 2'de olumlu değişkenler motivasyonsuzlukla negatif, içsel motivasyona doğru ise giderek kuvvetlenen pozitif ilişkiler göstermektedir. Bunun tersi olarak da olumsuz değişkenler motivasyonsuzlukla pozitif, içsel motivasyona doğru giderek kuvvetlenen negatif ilişkiler göstermektedir. Örneğin, Çalışma 2'nin örneklemine büyüklük olarak yakın olan Fransız örneklemi $(\mathrm{N}=335)$ dönüşümcü liderlik ile motivasyonsuzluk için -.16, içsel motivasyon ile ise .44'lük korelasyon katsayıları gösterirken, bu katsayılar içsel motivasyona doğru düzenli olarak olumlulaşma ve kuvvetlenme göstermiştir. Benzer şekilde işten ayrılma isteği için ise motivasyonsuzluk ile .37 ve içsel motivasyon ile -.47'lik bir korelasyon katsayısı gözlenmektedir. Bu çalışmalardaki etki büyüklükleri aralığı Çalışma 2'de elde edilen etki büyüklükleri aralığından daha yüksektir. Ancak, şu noktanın altı çizilmelidir ki, Gagné ve arkadaşlarının çalışması iş hayatı ve değerleri açısından Türk kültüründen ayrışabilecek örneklemlere yer vermiştir. Bu yüzden korelasyonların etki büyüklükleri yerine yönleri (pozitif ya da negatif) üzerinden değerlendirilmeleri hem daha fazla genellenebilir sonuçlara ulaşmamızı sağlayacak hem de ÇBİMÖ’nün küresel kullanımı açısından Türk örnekleminin de benzeri sonuçlarının literatüre katkısı olarak değerlendirilebilecektir.

Çalışma 2'nin liderlik stillerinin çalışanların içsel motivasyonları ve özdeşleştirilmiş düzenlemeleri ile olan ilişkilerine dair hipotezleri desteklenmiştir. Başka bir deyişle hem dönüşümcü hem de babacan liderlik stili ya da davranışları, çalışanların işlerini hem zevkli ve ilginç bulmalarına (içsel motivasyon) hem de yaptıkları işi kendi değerleriyle uyumlu ve önemli bulmalarına (özdeşleştirilmiş düzenleme) katkı sağlamaktadır. Bu sonuçlar 1şığında, yöneticilerin dönüşümcü ve babacan liderlik stillerinin çalışanların özerk motivasyonları üzerinde benzer olumlu etkileri olduğu söylenebilir. Benzer sonuçlar, yine Türkiye'de yapılan yakın tarihli bir çalışmada Göncü ve arkadaşları (2014) tarafindan rapor edilmiştir. Bu çalışmanın bulguları, iki liderlik stilinin de çalışanların yöneticiye duydukları güveni olumlu yönde etkilediğini ve güvenin liderlik stilleri ile içsel motivasyon türleri olarak ele alınan psikolojik yetkelenme ve kurumla özdeşleşme arasındaki ilişkide aracı rol oynadığını göstermiştir. Yazarlar, dönüşümcü liderlik stili ile babacan liderlik stilinin Türk kültürel bağlamında benzer olumlu sonuçlar doğurduğunu ve bireycilikte yüksek olan kültürel bağlamlardan farklı olarak, ülkemizde çalışanlar tarafından son derece benzer liderlik tipleri olarak algılanabildiklerini belirtmişlerdir. Aslında, Çalışma 2'de de Göncü ve arkadaşlarının iki liderlik tipi arasında yüksek derecede korelasyon $(r=.74, p<.01)$ bulan çalışmasına benzer olarak, iki liderlik tipi arasında oldukça yüksek korelasyon bulunması $(r=.89, p<.01)$ yazarların bu tespitini desteklemektedir ${ }^{4}$.

Çalışma 2'nin sonuçları, yalnızca, babacan liderlik stilinin statü hiyerarşisi ve otoriteyi koruma alt boyutunun çalışanların kontrollü motivasyonlarıyla ilişsili olduğunu ve genel olarak bakıldığında dönüşümcü ve babacan liderlik stillerinin çalışanların kontrollü motivasyonları ile ilişkili olmadığını göstermiştir. Bu açıdan da iki liderlik stili benzerlik göstermektedir. Başka bir deyişle, iki liderlik stili de çalışanların işlerini kendileriyle gurur duymak ve/ya kendilerinden utanç duymamak için iyi yapmaya çalışmalarını (içe yansıtılmış düzenleme) teşvik etmemekte; aynı zamanda gelecek eleştirilerden kaçınma ve/ya ödüllere ulaşma gibi güdülerine de (dıştan gelen düzenleme) etki etmemektedirler. Göncü ve arkadaşları (2014) babacan liderlik stilinin çalışanların izlenim yönetimi güdüleri üzerinde olumlu yönde etkisi olduğunu bulmuştur. Yani, babacan liderlik stiline sahip yöneticilerin çalışanları, bu liderlik stilinde düşük puan alan yöneticilerin çalışanlarına kıyasla, işyerinde daha olumlu algılanmak için çalışmadıkları zaman bile çalışıyor gibi görünme, diğerlerinin onayını alacak davranışlar sergileme eğilimlerini daha fazla göstermektedirler. Dolayısıyla, bu çalışmada da babacan yöneticilerle çalışanların eleştiri ve/ya maddi/manevi cezalardan kaçınmak ve/ya maddi/manevi ödüllere ulaşmak için işlerinde çaba sarf etme eğilimlerinin daha fazla olması beklenmiştir ancak bu önerme desteklenmemiştir. Diğer yandan, dönüşümcü liderlik stilinin dıştan gelen düzenlemeyle beklenen negatif ilişkiyi göstermemesi ise, bu liderlik stiline sahip yöneticilerin babacan liderliğe sahip

4 Bu noktada belirtmek gerekmektedir ki bu iki liderlik türü kavramsal olarak ayrıdırlar ve bu çalışmadaki verilerde de görgül olarak ayrı olmalarının daha kuvvetli istatistiksel sonuçlar sergilediği gözlemlenmiştir. Bu yüzden hem ölçümsel açıdan hem de alanyazınla uygunluğu bakımından iki liderlik türünün modelde ayrı olarak ele alınması ve sonuçlarının bu şekilde analiz edilmesinin daha bilgilendirici olacağı düșünülmektedir. Bu çalıșmada yapılan DFA sonuçları da iki liderlik tipinin maddelerinin ayrı ayrı gizil değişkenlere yüklendiği modelin $\left[\chi^{2}(766)=2249.27, \mathrm{GFI}=.76, \mathrm{CFI}=.87, \mathrm{TLI}=.87, \mathrm{RMSEA}=.06\right]$ aynı gizil değişkene yüklendiği modele $\left[\chi^{2}(778)=2902.70, \mathrm{GFI}=.72, \mathrm{CFI}=.81, \mathrm{TLI}=.80, \mathrm{RMSEA}=.08\right]$ oranla daha iyi uyum gösterdiğini ortaya koymaktadır $\left(\Delta \chi^{2}(12)=653.43, p<.01\right)$. 
yöneticilere kıyasla daha profesyonel bir iş yaklaşımına sahip olmalarına bağlı olabilir (Göncü ve ark., 2014). Bu tip yöneticilerin, performans-ödül ve performans-ceza ilişkilerini net bir şekilde tanımlamaları ve uygulanan kuralların tüm çalışanlar için geçerli olduğu mesajını vermeleri beklenmektedir. Dolayısıyla, tüm kuralların herkes için aynı olduğu bir işyerinde çalışanların motivasyonlarında maddi/manevi ödüller ve cezalar sebebiyle düşüş veya artış görülmüyor olabilir.

Yapısal eşitlik modelinin gösterdiği sonuçlarda babacan liderlik stilinin hem motivasyon hem de işten ayrılma niyeti ile gösterdiği anlamsız ilişki ise dikkat çekicidir. Bu ilişkiler her ne kadar korelasyon tablosunda anlamlı gözükse de önerilen modelde anlamlılıklarını kaybetmişlerdir. Bu durumun babacan liderlik ve dönüşümcü liderlik stilleri arasındaki kuvvetli ilişkiden kaynaklanması muhtemeldir. İstatistiksel olarak yüksek ölçüde ilişki gösteren bağımsız değişkenlerin, yordadıkları bağımlı değişkenlerdeki etkilerini kaybetmeleri baskılama etkisi olarak açıklanmaktadır (MacKinnon, Krull ve Lockwood, 2000). Bu çalışmada yüksek seviyede korelasyon gösteren iki bağımsız değişken, bağımlı değişken olan motivasyonu yordadığında, babacan liderliğin dönüşümcü liderliğin açıkladığından daha fazla varyans açıklayamadığı ve etkisinin dönüşümcü liderlik tarafından baskılandığı söylenebilir (Friedman ve Wall, 2005).

\section{Gelecekteki Araştırmalara ve Yöntemsel İyileştirmelere Yönelik Öneriler}

$\mathrm{Bu}$ çalışma dönüşümcü ve babacan liderlik stillerinin ÖBK'nın önerdiği çalışan motivasyonları üzerindeki etkileri ile bu motivasyon tiplerinin liderlik stilleri ile daha uzak sonuç değişkenleri arasındaki ilişkilerini inceleyen ilk çalışmadır. Gelecekte yapılacak olan çalışmalarda, iki liderlik stili birlikte ele alınmaya devam edilerek, özerk motivasyonlar ile benzer örüntü gösteren ilişkilerinde rol oynayan belirleyici değişkenler araştırılabilir. Örneğin, yine yakın zaman önce ülkemizde yapılan bir araştırma, çalışanların yaşları azaldıkça bireycilik eğilimlerinin ve güç elde etme ihtiyaçlarının arttığını göstermiştir (Göncü, 2013). Bu da görece genç çalışanların kendilerine bir aile büyüğü gibi davranan, zaman zaman tatl1-sert tavırlar sergileyen ve işyerindeki güç ve otoriteyi elinde tutan babacan yöneticileri yaşça daha büyük olan çalışanlara kıyasla daha az benimseyebileceklerini düşündürmektedir. Dolayısıyla, dönüşümcü ve babacan liderlik stillerinin çalışanların özerk motivasyonları ile ilişkisinde çalışanların yaşı belirleyici değişkenlerden biri olabilir ve farklı yaş gruplarından katılımcıların eşit olarak temsil edildiği örneklemlerde bu önerme test edilebilir. Gelecek çalışmalar ayrıca bu liderlik tiplerinin ÖBK tarafından önerilen ihtiyaçları ne derecede giderdiklerine odaklanabilir. Farklı liderlik tipleri, çalışanların farklı ihtiyaç türleri üzerinde daha fazla (ya da daha az) etkili olabilir. Örneğin, babacan liderlik tipine sahip yöneticiler çalışanların yakınlık ihtiyacını karşılayarak içsel motivasyonlarını ve/ya özdeşleştirilmiş düzenlemelerini arttırırken; dönüşümcü liderler çalışanların özerklik ve yeterlik ihtiyaçlarını babacan liderlere kıyasla daha fazla karşılayarak bu tip motivasyonların artmasını sağlıyor olabilirler. Hem Çalışma 2'nin verileriyle elde edilen korelasyon tablosu, hem de YEM ile test edilen önerilen model genel olarak kuramsal beklentilere uygun sonuçlar göstermektedir. $\mathrm{Bu}$ sonuçlara göre, Türk örnekleminde de çalışanların batı ülkelerindeki çalışanlara benzer şekilde dönüşümcü liderlik stilinden daha çok faydalandıkları ve bu tip liderliğin babacan liderlik stiline kıyasla çalışanlarda daha yüksek içsel motivasyon hissedilmesine ve daha az işten ayrılma niyeti oluşmasına katkı sağladığı önerilebilir. Yalnızca bu çalışmada elde edilen bulgular güçlü yarg1lara varmak için yeterli değildir ve gelecekte yapılacak olan çalışmalarda bu ilişkilerin farklı örneklem gruplarıyla ve bu ilişkilerde rol oynayabilecek aracı değişkenler (örn., yöneticiye duyulan güven, psikolojik kontrat) ve belirleyici değişkenler (örn., çalışılan sektör, çalışanın ve yöneticinin yaş ve cinsiyetleri) eklenerek test edilmesi tavsiye edilmektedir.

Her araştırma gibi, bu çalışmanın da bazı kısıtlılıkları mevcuttur. İlk olarak, her iki çalışmada da örneklem sayısı orta düzeydedir ve özellikle Çalışma 2'nin önerdiği modelin geliştirilerek daha geniş örneklemlerle test edilmesi faydalı olacaktır. İkinci olarak, veri tek bir kaynaktan toplanmıştır ve hem yöneticilerin liderlik stilleri hem de motivasyon tipleri, duygusal yakınlık, işyerinde erteleme davranışları ve işten ayrılma niyetleri çalışanlar tarafından değerlendirilmiştir. İleride yapılacak çalışmalarda yöneticilerin liderlik stilleri farklı kaynaklar tarafından değerlendirilebilir ve ortalama puanlar liderlik stili değerlendirmesi olarak analizlere dâhil edilebilir. Ayrıca, iki liderlik tipi arasındaki son derece yüksek korelasyon büyük ölçüde iki liderlik tipinin benzer şekilde algılandığ1 anlamına gelebilir. Tablo 3 'te de görülmektedir ki iki liderlik tipinin alt boyutları arasındaki korelasyonlar .52 ile .85 arasında değişmektedir ve pozitif ilişkilidirler. $\mathrm{Bu}$ alt ölçeklerin maddelerinin ortalaması alınarak hazırlanan babacan ve dönüşümcü liderlik tipi değişkenlerinin bu yüzden .89 korelasyon göstermesi beklenebilir. Diğer yandan, alanyazında her iki liderlik tipini birlikte ele alan az sayıdaki çalışmanın bulguları da bu çalışmanın bulgularına benzerdir. Örneğin, Göncü ve arkadaşları (2014) Türkiye'de gerçekleştirdikleri bir çalışmada iki liderlik tipi arasındaki korelasyonu .74 olarak rapor etmiştir. Karakitapoğlu-Aygün ve Gümüşlüoğlu (2013) babacan liderlik ve dönüşümcü liderliğin iki alt boyutu (ilham veren karizmatik liderlik ve aktif-entelek- 
tüel uyarıcı liderlik) arasındaki korelasyonların .89 ve .91 arasında değiştiğini bulmuştur. Sonuçlar önceki araştırmalarla tutarlı olsa bile babacan liderlik ve dönüşümcü liderlik türleri arasındaki yüksek korelasyon dolayısıyla bu çalışmada bir baskılama etkisi gerçekleşmiş olabilir (MacKinnon ve ark., 2000) ve bu durum yöntemsel bir hatadan da kaynaklanmış olabilir. Anket formunda babacan ve dönüşümcü liderlik tipi sorularının birlikte ve arka arkaya sorulması "sessiz kalma/teslimiyet yanlılı̆̆ı" olarak bilinen çoklu yöntem sapmasına neden olmuş olabilir (Podsakoff, Mackenzie, Lee ve Podsakoff, 2003). Gelecekteki çalışmalarda bu iki kavramla ilgili veri toplanırken bu hususa dikkat edilmelidir. Son olarak, veri tek bir zamanda anket yöntemi kullanılarak toplanmıştır. $\mathrm{Bu}$ durum, ortak yöntem yanlılığına neden olabilir (örn., Johnson, Rosen ve Djurdjevic, 2011). Gelecekteki çalışmalarda sosyal beğenilirlik ve negatif duygulanım gibi yanlılığa neden olan bazı temel değişkenlerin (Johnson ve ark., 2011) araştırmalara dâhil edilmesi ve temel değişkenler üzerindeki etkilerinin incelenmesi önerilmektedir.

\section{Sonuç}

Sonuç olarak, bu araştırma ÖBK'nın önermeleri doğrultusunda geliștirilmiș ve ișyeri motivasyonuna yönelik güçlü bir ölçüm aracı olan ÇBİMÖ’nün Türkçeye uyarlama çalışmasını güvenirlik ve geçerlik analizleriyle gerçekleştiren ve bu ölçeği kullanarak çalışan motivasyonlarının Türkiye bağlamında yaygın olarak görülen dönüşümcü ve babacan liderlik stilleri ve çalışanların işten ayrılma niyetleriyle olan ilişkilerini ayrıntılı bir şekilde analiz eden ilk çalışmadır. Bulguların ÖBK konusunda iş ve örgüt psikolojisi alanında yapılacak çalışmalara kuramsal katkı sağlaması, araştırmacılar için yol gösterici olması ve uygulamacılara faydalı bilgi ve öneriler sunması ümit edilmektedir.

\section{Kaynaklar}

Abassi, S. M. ve Hollman, K. W. (2000). Turnover: The real bottom line. Public Personnel Management, 29(3), 333-342. http://dx.doi. org/10.1177/009102600002900303

Alatawi, M.A. (2017). Can transformational managers control turnover intention? SA Journal of Human Resource Management, 15(1), 1-6. https://doi. org/10.4102/sajhrm.v15i0.873

Allen, N. J. ve Meyer, J. P. (1990). The measurement and antecedents of affective, continuance, and normative commitment to the organization. Journal of Occupational Psychology, 63(1), 1-18. http://dx.doi. org/10.1111/j.2044-8325.1990.tb00506.x

Arbuckle, J. L. (2013). Amos (Version 22.0). Computer Program. Chicago: SPSS/IBM.

Armstrong, M. (1998). A handbook of personnel management practice, (6th ed). London: Kogan Page Limited.

Avolio, B. J. ve Bass, B. M. (2001). Developing potential across a full range of Leadership TM: Cases on transactional and transformational leadership. New York, NY: Psychology Press.

Avolio, B. J., Bass, B. M. ve Jung, D. I. (1999). Re-examining the components of transformational and transactional leadership using the Multifactor Leadership. Journal of Occupational and Organizational Psychology, 72(4), 441-462. http://dx.doi. org/10.1348/096317999166789

Aycan, Z. (2000). Cross-cultural industrial and organizational psychology: Contributions, past developments, and future directions. Journal of Cross-Cultural Psychology, 31(1), 110-128. http://dx.doi. org/10.1177/0022022100031001009

Aycan, Z. (2006). Paternalism. Indigenous and cultural psychology içinde (445-466). Springer, Boston, MA.

Aycan, Z., Schyns, B., Sun, J. M., Felfe, J. ve Saher, N. (2013). Convergence and divergence of paternalistic leadership: A cross-cultural investigation of prototypes. Journal of International Business Studies, 44(9), 962-969. http://dx.doi.org/10.1057/ jibs. 2013.48

Bakoğlu Deliorman, R., Taştan Boz, İ., Yiğit, İ. ve Y1ldız, S. (2009). Tükenmişliği ölçmede alternatif bir araç: Kopenhag tükenmişlik envanterinin Marmara Üniversitesi akademik personeli üzerine uyarlamas1, İstanbul Üniversitesi Yönetim Dergisi, 63, 77-98.

Bass, B. M. (1999). Two decades of research and development in transformational leadership. European Journal of Work and Organizational Psychology, 8(1), 9-32. http://dx.doi.org/10.1080/135943299398410 
Blau, G. ve Boal, K. (1989). Using job involvement and organizational commitment interactively to predict turnover. Journal of Management, 15(1), 115-127. http://dx.doi.org/10.1177/014920638901500110

Caillier, J. G. (2016a). Do transformational leaders affect turnover intentions and extra-role behaviors through mission valence?. The American Review of Public Administration, 46(2), 226-242. http:// dx.doi.org/10.1177/0275074014551751

Caillier, J. G. (2016b). Linking transformational leadership to self-efficacy, extra-role behaviors, and turnover intentions in public agencies: The mediating role of goal clarity. Administration \& Society, 48(7), 883-906. http://dx.doi. org/10.1177/0095399713519093

Cem Ersoy, N., Born, M. P., Derous, E. ve van der Molen, H. T. (2012). The effect of cultural orientation and leadership style on self-versus other-oriented organizational citizenship behaviour in Turkey and the Netherlands. Asian Journal of Social Psychology, 15(4), 249-260. https://doi.org/10.1111/ j.1467-839X.2012.01380.x

Chhokar, J. S., Brodbeck, F. C. ve House, R. J. (Eds.). (2008). LEA's organization and management series. Culture and leadership across the world: The GLOBE book of in-depth studies of 25 societies. Mahwah, NJ, US: Lawrence Erlbaum Associates Publishers.

Clark, J., Quast, L. N., Jang, S., Wohkittel, J., Center, B., Edwards, K. ve Bovornusvakool, W. (2016). GLOBE Study culture clusters: Can they be found in Importance ratings of managerial competencies? European Journal of Training and Development, 40(7), 534-553. https://doi.org/10.1108/EJTD-032016-0016

Çivilidağ A. ve Şekercioğlu G. (2017). Çok boyutlu iş motivasyonu ölçeğinin Türk kültürüne uyarlanmas1. Mediterranean Journal of Humanities, 7(1), 143-156.

Deci, E. L., Connell, J. P. ve Ryan, R. M. (1989). Self-determination in a work organization. Journal of Applied Psychology, 74(4), 580. http://dx.doi. org/10.1037/0021-9010.74.4.580

Deci, E. L., Olafsen, A. H. ve Ryan, R. M. (2017). Self-determination theory in work organizations: The state of a science. Annual Review of Organizational Psychology and Organizational Behavior, 4, 19-43. http://dx.doi.org/10.1146/annurev-orgpsych-032516-113108

Deci, E. ve Ryan, R. M. (1985). Intrinsic motivation and self-determination in human behavior. Boston, MA: Springer Science ve Business Media. http:// dx.doi.org/10.1007/978-1-4899-2271-7
Deci, E. L. ve Ryan, R. M. (2000). The" what" and" why" of goal pursuits: Human needs and the self-determination of behavior. Psychological Inquiry, 11(4), 227-268. http://dx.doi.org/10.1207/ S15327965PLI1104_01

Deci, E. L. ve Ryan, R. M. (2008). Self-determination theory: A macrotheory of human motivation, development, and health. Canadian Psychology/Psychologie Canadienne, 49(3), 182. http://dx.doi. org/10.1037/a0012801

Deci, E. L. Vallerand, R. J., Pelletier, L. G., ve Ryan, R. M. (1991). Motivation and education: The self-determination perspective. Educational Psychologist, 26(3-4), 325-346. http://dx.doi.org/10.1080/00461 520.1991 .9653137

Eyal, O. ve Roth, G. (2011). Principals'leadership and teachers' motivation: Self-determination theory analysis. Journal of Educational Administration, 49(3), 256275. http://dx.doi.org/10.1108/09578231111129055

Fernet, C., Trépanier, S. G., Austin, S., Gagné, M. ve Forest, J. (2015). Transformational leadership and optimal functioning at work: On the mediating role of employees' perceived job characteristics and motivation. Work \& Stress, 29(1), 11-31. http://dx.doi. org/10.1080/02678373.2014.1003998

Friedman, L. ve Wall, M. (2005). Graphical views of suppression and multicollinearity in multiple linear regression. The American Statistician, 59(2), 127136. https://doi.org/10.1198/000313005X41337

Fu, P. P., Tsui, A. S., Liu, J. ve Li, L. (2010). Pursuit of whose happiness? Executive leaders' transformational behaviors and personal values. Administrative Science Quarterly, 55(2), 222-254. http://dx.doi. org/10.2189/asqu.2010.55.2.222

Gagné, M. (2003). Autonomy support and need satisfaction in the motivation and well-being of gymnasts. Journal of Applied Sport Psychology, 15(4), 372390. http://dx.doi.org/10.1080/714044203

Gagné, M., Chemolli, E., Forest, J. ve Koestner, R. (2008). A temporal analysis of the relation between organisational commitment and work motivation. Psychologica Belgica, 48(2-3). http://dx.doi. org/10.5334/pb-48-2-3-219

Gagné, M., Forest, J., Vansteenkiste, M., Crevier-Braud, L., Van den Broeck, A., Aspeli, A. K., ... ve Halvari, H. (2014). The multidimensional work motivation scale: Validation evidence in seven languages and nine countries. European Journal of Work and Organizational Psychology, 24(2), 178-196. http:// dx.doi.org/10.1080/1359432X.2013.877892

Gillet, N., Gagné, M., Sauvagère, S. ve Fouquereau, E. (2013). The role of supervisor autonomy support, organizational support, and autono- 
mous and controlled motivation in predicting employees' satisfaction and turnover intentions. European Journal of Work and Organizational Psychology, 22(4), 450-460. http://dx.doi.org/10.1080/1359432X.2012.665228

Green A. E., Miller E .A. ve Aarons, G. A. (2013). Transformational leadership moderates the relationship between emotional exhaustion and turnover intention among community mental health providers. Community Mental Health Journal, 49(4), 373379. http://dx.doi.org/10.1007/s10597-011-9463-0

Göncü, A. (2013). Farklı olan değil ayn(a) olan kazanır: Bir yönetici olarak grup protipi lider olmak. ODTÜ Yayıncılık, Ankara, Türkiye.

Göncü, A., Aycan, Z. ve Johnson, R. E. (2014). Effects of paternalistic and transformational leadership on follower outcomes. International Journal of Management and Business, 5(1), 36-58.

Göncü Köse, A. ve Metin, U. B. (2018). Linking leadership style and workplace procrastination: The role of organizational citizenship behavior and turnover intention. Journal of Prevention \& Intervention in the Community, 46(3), 245-262. https://doi.org/10. 1080/10852352.2018.1470369

Hayes, A. F. ve Preacher, K. J. (2014). Statistical mediation analysis with a multicategorical independent variable. British Journal of Mathematical and Statistical Psychology, 67(3), 451-470. http://dx.doi. org/10.1111/bmsp. 12028

Hu, L. T. ve Bentler, P. M. (1999). Cutoff criteria for fit indexes in covariance structure analysis: Conventional criteria versus new alternatives. Structural Equation Modeling: A Multidisciplinary Journal, 6(1), 1-55. http://dx.doi. org/10.1080/10705519909540118

Hughes, L. W., Avey, J. B. ve Nixon, D. R. (2010). Relationships between leadership and followers' quitting intentions and job search behaviors. Journal of Leadership \& Organizational Studies, 17(4), 351362. https://doi.org/10.1177/1548051809358698

Johnson, R. E., Rosen, C. C. ve Djurdjevic, E. (2011). Assessing the impact of common method variance on higher-order multidimensional constructs. Journal of Applied Psychology, 96, 744-761. http:// dx.doi.org/10.1037/a0021504

Karakitapoğlu-Aygün, Z. ve Gümüşlüoğlu, L. (2013). Dönüştürücü liderliğin Türkiye bağlamında yeniden kavramsallaştırılması. Türk Psikoloji Dergisi, 28(72), 105-124.

Kuvaas, B. (2006a). Work performance, affective commitment, and work motivation: The roles of pay administration and pay level. Journal of Organizational Behavior: The International Journal of Industrial, Occupational and Organizational Psychology and Behavior, 27(3), 365-385. http:// dx.doi.org/10.1002/job.377

Kuvaas, B. (2006b). Performance appraisal satisfaction and employee outcomes: Mediating and moderating roles of work motivation. The International Journal of Human Resource Management, 17(3), 504-522. http://dx.doi.org/10.1080/09585190500521581

Liao, S. H., Widowati, R., Hu, D. C. ve Tasman, L. (2017). The mediating effect of psychological contract in the relationships between paternalistic leadership and turnover intention for foreign workers in Taiwan. Asia Pacific Management Review, 22(2), 8087. http://dx.doi.org/10.1016/j.apmrv.2016.08.003

MacKinnon, D. P., Krull, J. L. ve Lockwood, C. M. (2000). Equivalence of the mediation, confounding and suppression effect. Prevention Science, 1(4), 173181. http://dx.doi.org/10.1023/A:1026595011371

Markus, H. R. ve Kitayama, S. (1991). Culture and the self: Implications for cognition, emotion, and motivation. Psychological Review, 98(2), 224-253.

Metin, U. B., Taris, T. W. ve Peeters, M .C. W. (2016). Measuring procrastination at work and its associated workplace aspects. Personality and Individual Differences, 101, 254 - 263. http://dx.doi. org/10.1016/j.paid.2016.06.006

Mowday R. T., Steers, R. M. ve Porter, W. L. (1997). The measurement of organizational commitment. Journal of Vocational Behavior, 14, 224-247. https:// doi.org/10.1016/0001-8791(79)90072-1

Moynihan, D. P. ve Landuyt, N. (2008). Explaining turnover intention in state government: Examining the roles of gender, life cycle, and loyalty. Review of Public Personnel Administration, 28(2), 120-143. http://dx.doi.org/10.1177/0734371X08315771

Nunnally, J.C. (1977), Psychometric Theory, (2nd ed.). McGraw-Hill, New York, NY.

Olafsen, A. H., Halvari, H., Forest, J. ve Deci, E. L. (2015). Show them the money? The role of pay, managerial need support, and justice in a self-determination theory model of intrinsic work motivation. Scandinavian Journal of Psychology, 56(4), 447-457. https://doi.org/10.1111/sjop.12211

Parker, S. L., Jimmieson, N. L. ve Amiot, C. E. (2017). The motivational mechanisms underlying active and high-strain work: Consequences for mastery and performance. Work \& Stress, 31(3), 233-255. http://dx.doi.org/10.1080/02678373.2017.1303551

Podsakoff, P. M., MacKenzie, S. B., Lee, J. Y., ve Podsakoff, N. P. (2003). Common method biases in behavioral research: A critical review of the literature and recommended remedies. Journal of Applied Psychology, 88(5), 879-903. 
Riggio, R. E. (2013). Introduction to industrial/organizational psychology (6th ed.) (L. W. Porter, Ed.). New York, NY: Harper Collins College Publishers.

Ryan, R. M. ve Deci, E. L. (2017). Self-determination theory: Basic psychological needs in motivation, development, and wellness. New York, NY: Guilford Publications. http://dx.doi.org/10.1007/97894-007-0753-5 2630

Shim, M. (2010). Factors influencing child welfare employee's turnover: Focusing on organisational culture and climate. Children and Youth Services Review, 32(6), 847-856. https://doi.org/10.1016/j. childyouth.2010.02.004

Shuck, B., Peyton Roberts, T. ve Zigarmi, D. (2018). Employee perceptions of the work environment, motivational outlooks, and employee work intentions: An HR practitioner's dream or nightmare?. Advances in Developing Human Resources, 20(2), 197213. http://dx.doi.org/10.1177/1523422318757209

Steers, R. M., Mowday, R. T. ve Shapiro, D. L. (2004). The future of work motivation theory. Academy of Management Review, 29(3), 379-387. http://dx.doi. org/10.5465/amr.2004.13670978

Steers, R. M. ve Porter, L. W. (Eds.) (1991). Motivation and work behavior (5th ed.). New York, NY: McGraw-Hill.

Trépanier, S. G., Forest, J., Fernet, C. ve Austin, S. (2015). On the psychological and motivational processes linking job characteristics to employee functioning: Insights from self-determination theory. Work \& Stress, 29(3), 286-305. http://dx.doi.org /10.1080/02678373.2015.1074957

Uğurluoğlu Ö., Uğurluoğlu Aldoğan E., Turgut M. ve Özatkan Y. (2018). The effect of paternalistic leadership on job performance and intention to leave the job. Journal of Health Management, 20(1), 4655. http://dx.doi.org/10.1177/0972063417747700

Wasti, S. A. (1999). Organizational commitment and collectivism: The case of Turkey, Yayınlanmamış doktora tezi, University of Illinois, Chicago. 
Ek. Çok Boyutlu İş Motivasyonu Ölçeği (ÇBİMÖ)

YÖNERGE. Lütfen aşağıdaki ifadeleri değerlendirirken "şu anki işinizle ilgili gösterdiğiniz/göstereceğiniz gayretin nedenlerini” düşününüz ve aşağıdaki 7 basamaklı ölçeği kullanarak değerlendiriniz. Her bir madde için, ölçekte görüşünüze en uygun olan ifadenin üzerindeki rakamı maddenin sonunda verilen sütuna yazınız.

\begin{tabular}{|c|c|c|c|c|c|c|}
\hline 1 & 2 & 3 & 4 & 5 & 6 & 7 \\
\hline $\begin{array}{c}\text { Kesinlikle } \\
\text { Katılmıorum }\end{array}$ & Katılmıorum & $\begin{array}{c}\text { Biraz } \\
\text { Katılmıorum }\end{array}$ & Kararsızım & $\begin{array}{c}\text { Biraz } \\
\text { Katıliyorum }\end{array}$ & Katıliyorum & $\begin{array}{c}\text { Kesinlikle } \\
\text { Katıllyorum }\end{array}$ \\
\hline
\end{tabular}

\section{ŞU ANKİ İŞINIZII YAPMAYA NEDEN GAYRET GÖSTERIYORSUNUZ/GÖSTERIRSIINIZ?}

1. Göstermiyorum, çünkü işimde zamanımı gerçekten boşa harcadığımı hissediyorum. (Motivasyonsuzluk 1)

2. Başkalarının (örneğin, amirim/yöneticim, meslektaşlarım, ailem, müşteriler) onayını almak için. (Dıştan Gelen Sosyal Düzenleme 1)

3. İşimde yeterince çaba gösterirsem işverenim, yöneticim, vb. tarafından maddi olarak ödüllendirileceğim için. (Dıştan Gelen Maddi Düzenleme 1)

4. Çünkü kendime bu işi yapabileceğimi kanıtlamak zorundayım. (İçe Yansıtılmış Motivasyon 1) ${ }^{1}$

5. Çünkü kişisel olarak bu iş için gayret göstermenin önemli olduğunu düşünüyorum. (Özdeşleştirilmiş Düzenleme 1)

6. Çünkü işimi yaparken eğleniyorum. (İçsel Motivasyon 1)

7. Çok az gayret gösteriyorum çünkü bu işin çaba harcamaya değer bir iş olduğunu düşünmüyorum. (Motivasyonsuzluk 2)

8. Başkalarının (örneğin, amirim/yöneticim, meslektaşlarım, ailem, müşteriler) bana daha fazla saygı duymaları için. (Dıştan Gelen Sosyal Düzenleme 2)

9. İşimde yeterince çaba gösterirsem işverenim, yöneticim, vb. tarafından işimi kaybetmemem garanti altına alınacağ için. (Dıştan Gelen Maddi Düzenleme 2)

10. Çünkü böyle yapmak kendimle gurur duymamı sağlıyor. (İçe Yansıtılmış Motivasyon 2)

11. Çünkü bu işe çaba harcamak, benim kişisel değerlerimle örtüşüyor. (Özdeşleştirilmiş Düzenleme 2)

12. Çünkü işimde yaptıklarım heyecan vericidir. (İçsel Motivasyon 2)

13. Bu işi neden yaptığımı bilmiyorum, manasız bir iş. (Motivasyonsuzluk 3)

14. Başkaları (örneğin, amirim/yöneticim, meslektaşlarım, ailem, müşteriler) tarafından eleştirilmekten kaçınmak için. (Dıştan Gelen Sosyal Düzenleme 3)

15. İşimde yeterince çaba göstermezsem, işimi kaybetme riskine gireceğim için. (Dıştan Gelen Maddi Düzenleme 3)

16. Çünkü aksi takdirde kendimden utanırdım. (İçe Yansıtılmış Motivasyon 3)

17. Çünkü bu işe çaba harcamak bana anlamlı geliyor. (Özdeşleştirilmiş Düzenleme 3)

18. Çünkü yaptığım iş ilginçtir. (İçsel Motivasyon 3)

19. Çünkü aksi takdirde kendimi kötü hissederdim. (İçe Yansıtılmış Motivasyon 4)

1 Çalışma 1'deki DFA analizleri sonucunda ölçekten çıkarılmış olan madde. 


\section{Summary Which Leader Makes Us Stay and How? The Mediating Role of Multidimensional Work Motivation}

\author{
Aslı Göncü Köse \\ Çankaya University
}

Motivation can be described as the main drive that determines the reason and direction of human behavior. This fundamental construct is one of the most frequently studied concepts in work and organizational psychology research due to its importance for understanding specific work behaviors, such as performance or turnover intention. Arguably, the most dominant and studied motivation theory is self-determination theory (SDT; Deci \& Ryan, 1985).

SDT is a motivation theory that conceptualizes motivation on a continuum that represents three domains, namely amotivation, extrinsic motivation, and intrinsic motivation. Amotivation is characterized as a state where individuals lack the motivation to start an action and it symbolizes the negative end of the SDT continuum. Extrinsic motivation is a state where individuals' behaviors are determined by an instrumental reason, such as avoiding penalization or improving self-respect. According to SDT, extrinsic motivation can be observed through three separate subdimensions. These are external regulation (i.e., performing an activity due to external punishment or rewards), introjected regulation (i.e., performing an activity due to avoiding guilt or shame), and identified regulation (i.e., performing an activity due to its personal value or meaning). Finally, intrinsic motivation represents the most self-determined dimension of human motivation and can be defined as performing an activity on a volitional basis because one finds it pleasurable, meaningful, and important. Theoretically, intrinsic motivation is associated mostly with positive outcomes because it stimulates the basic psychological human needs, namely autonomy, relatedness, and competence. In case these three needs are not satisfied, individuals are more likely to experience an externally regulated motivation style.

Within the occupational context, there is considerable research that examined the relationship between leadership styles and motivation. A reason for this is the cognitive-behavioral impact of different leadership styles on employee motivation. One of the most preva-

\author{
U. Baran Metin \\ Utrecht University
}

lent leadership styles in the western work environment is the transformational leadership (TL) style. TL style motivates employees through stimulating inspiration, creating vision, and empowering them. However, in the non-western work context another leadership style, namely paternalistic leadership (PL) appears as a helpful approach. In this leadership style, the leader adopts a dominant approach and acts towards the employees as part of an extended family, by genuinely caring for their needs and development requirements.

This paper presents two interdependent studies. Study 1 aims to investigate the psychometric characteristics of the Multidimensional Work Motivation Scale (MWMS) within the Turkish occupational context. The MWMS is a frequently used instrument, which measures employee motivation in line with SDT (Gagné et al., 2014). To our knowledge, there is only one study which tested the psychometric characteristics (specifically, the factorial structure and item loadings) of the MWMS in a Turkish sample. Moreover, the current study has the notion to test the convergent and discriminant validity of the MWMS with two important employee behaviors, namely procrastination and affective commitment. Study 2 aims to examine how motivation is linked with TL and PL styles, as well as with turnover intentions. More specifically, it is intended to test the mediation role of work motivation between the leadership styles and employees' turnover intentions by using structural equation modeling. Therefore, this paper enhances the work and organizational psychology literature by validating a globally important scale in Turkish culture, as well as displaying the impact of motivation in relation with leadership styles and turnover intentions. More specifically, a heuristic model was proposed and tested where employee motivation would mediate the relationship of PL and TL styles with turnover intentions.

TL style refers to the type of leaders who enhance intrinsic motivation and performance through four characteristics (Avolio \& Bass, 2001). These characteristics

Address for Correspondence: Assoc. Prof. Aslı Göncü Köse, Çankaya University, Faculty of Arts and Sciences, Department of Psychology, Yukariyurtçu Mahallesi Mimar Sinan Caddesi No:4 06530, Etimesgut / Ankara

E-mail: agoncu@cankaya.edu.tr 
are (a) idealized influence (the leader appears as an ideal role model for the followers); (b) inspirational motivation (the leader has the ability to inspire and motivate the followers); (c) individualized consideration (the leader displays concern and interest for the followers' needs); and (d) intellectual stimulation (the leader stimulates innovative and creative ideas for the followers). Since TL style has positive influence on employees' intrinsic motivation, it is expected that motivation would mediate the negative link between TL style and turnover intentions.

On the other hand, PL style can be described as the leadership approach in which leaders act as hierarchical figures (Aycan, 2000). They genuinely get concerned about the professional and private lives of the followers, protect them and expect them to be loyal. PL style is characterized by (a) creating a family environment at work; (b) creating personal relationships with employees; (c) getting involved in the non-work lives of employees; (d) expecting loyalty; and (e) preserving hierarchy and authority. In non-western cultures, PL appears as a functional and common style. Due to an enhanced sense of trust, relatedness, and dedication, PL leads to specific positive outcomes such as increased performance and decreased procrastination. Nevertheless, there is not sufficient research that address how PL style is related to motivation. In the present study, it is expected that PL style will show a negative relationship with turnover intentions and this relationship will be mediated via employee motivation. Therefore, the hypotheses of Study 2 are as follows:

Hypothesis 1: Managers' TL style will be positively associated with employees' autonomous motivations (i.e., intrinsic motivation and identified regulation).

Hypothesis 2: Managers' TL style will be negatively associated with employees' amotivation and controlled motivations (i.e., extrinsic regulation and introjected motivation).

Hypothesis 3: Family atmosphere in the workplace, individualized relationships with subordinates, and involvement in non-work life dimensions of PL will be positively associated with employees' autonomous motivations (i.e., intrinsic motivation and identified regulation) and introjected motivations.

Hypothesis 4: Loyalty expectation and status hierarchy and authority dimensions of PL will be positively associated with employees' extrinsic regulation.

Hypothesis 5: Managers' PL style will be negatively associated with employees' amotivation.

Hypothesis 6: Managers' TL style will be negatively associated with employees' turnover intentions.

Hypothesis 7: Employees' motivations (motivation scores) will partially mediate the relationship between managers' TL style and employees' turnover intentions.
Hypothesis 8: Managers' PL style will be negatively associated with employees' turnover intentions.

Hypothesis 9: Employees' motivations (motivation scores) will partially mediate the relationship between managers' PL style and employees' turnover intentions.

\section{Study 1}

\section{Method}

In Study 1, the conceptual application of SDT with the specific dimensions of amotivation, extrinsic regulation, introjected motivation, identified regulation, and intrinsic motivation was tested in a sample of 456 Turkish white-collar employees by using the MWMS (Gagné et al., 2014). For validity testing, ten items of the Affective Commitment Scale by Allen and Meyer (1990) and 12 items of the Procrastination at Work Scale by Metin, Taris, and Peeters (2016) were used.

\section{Results}

As expected, confirmatory factor analysis of the MWMS showed similar characteristics to its original factorial structure in the Turkish dataset. Only notable differences were the insufficient factor loading of one introjected motivation item and the significantly better goodness-of-fit of a model where the social and material extrinsic regulation types were not distinguished. Hence, the 18-item, 5-factor MWMS was accepted as the final model, and the validation analyses were applied on this solution. Convergent and discriminant validity analyses showed that more controlled motivation types were positively correlated with affective commitment and negatively correlated with procrastination at work. These results showed that MWMS exhibits similar goodnessof-fit characteristics in the Turkish sample to the original conceptual model.

\section{Study 2}

\section{Method}

In Study 2, data were collected from 388 Turkish office employees. The MWMS which was validated in Study 1 was used alongside the Turkish version of the 20-item MLQ Form 5X for transformational leadership (Avolio, Bass, \& Jung, 1999), the 21-item Paternalistic Leadership Scale (Aycan, 2006) and the 4-item Turnover Intention Scale (Blau \& Boal, 1989).

\section{Results}

According to the correlations between study variables, TL style had a positive association with autono- 
mous motivations (i.e., intrinsic motivation and identified regulation) and a negative association with amotivation. Family atmosphere in the workplace, individualized relationships with subordinates and involvement in non-work life dimensions of PL were positively associated with employees' autonomous motivations (intrinsic motivation and identified regulation); however, the relationships between these three dimensions and introjected motivations were not significant. Status hierarchy and authority dimension of PL was positively associated with employees' extrinsic regulation; whereas, the link of loyalty expectation dimension with extrinsic regulation was non-significant. As expected, PL was negatively associated with employees' amotivation. Both TL and PL were negatively associated with employees' turnover intentions. The structural equation modeling results showed that only TL style had a significant indirect link to turnover intention through motivation and motivation partially mediated this relationship.

\section{Discussion}

These results imply three important conclusions. First of all, the Turkish version of the five-factor MWMS demonstrated acceptable psychometric characteristics. Therefore, it appears to be a useful tool to measure employee motivation based on SDT. Secondly, in Turkish sample, both PL and TL styles showed very similar characteristics. For instance, both styles had positive correlations with intrinsic motivation and identified regulation and negative correlations with amotivation. Moreover, the strong link between TL and PL styles may imply that in Turkish culture, both styles are interrelated with each other in terms of exhibiting a leadership pattern and are positively linked to desirable components of motivation. Thirdly, TL style appears as a superior style over PL due to its statistical power in the proposed heuristic model. Structural equation modeling and bootstrapping analyses showed that TL style had a greater influence on increased employee motivation and decreased turnover intentions compared to PL style. These findings showed that the study sample displayed comparable characteristics to Western work values. To sum up, both leadership styles seem to aspire employees in a positive way by stimulating their autonomous motivation (as employees feel more proud of their work and find it more interesting) and by potentially limiting their turnover intentions.

There are three main limitations of this study. First of all, the sample sizes in both studies were moderate, hence further empirical research is needed to test the relationships found in this study in order to enhance our understanding of leadership styles, motivation, and turnover intention. Second, data were collected from single resource. Finally, the scales were rated on self-report scales, which may have raised the concern for common-method variance. Future studies are encouraged to use different methods of information collection, such as actual turnover figures or performance reviews.

As a conclusion, these studies have both theoretically and practically noteworthy implications. They are among the first to validate and test the conceptual structure and reliability of a very useful employee motivation scale, the MWMS, in Turkish culture. Researchers are encouraged to use this tool for assessing employee motivation in line with SDT in the future. Moreover, the relationships among leadership styles, motivation, and turnover intention were examined for the first time in a Turkish sample. The results both enrich our understanding of the links between these variables in Turkish context and provide managers valuable insight as to how to motivate their employees and potentially limit their turnover intentions. 